\title{
THE RELATION OF PANCREATIC ORGANOTHERAPY TO KETOGENESIS *
}

\author{
EDWIN GARVEY KIRK, M.D. \\ CHICAGO
}

\section{INTRODUCTION}

The earlier trials, both laboratory and clinical, of pancreatic opotherapy, were conceived and undertaken at a time when the groundproblems of diabetes - almost coextensive as they are with the whole domain of pathometabolism - were not so clearly defined as at present. Nevertheless, on historical consideration of these attempts it becomes obvious that the propelling forces behind them all were, first, the urgent demand for a successful therapy, and, following that, the vague assumption, dating from or even antedating von Mering and Minkowski's classic work, that the pathogenetic basis of the clinical entity diabetes is the absence or deficiency of a pancreatic hormone or internal secretion necessary in some sense to carbohydrate utilization. Whether this basal assumption of an internal secretion shall prove valid or not, it is certain that the attempts at pancreatic organotherapy have amply justified themselves, not as yet by realizing much of practical value to the clinician, but by virtue of the increasing light they have thrown on the problems of general and of diabetic metabolism.

The earlier workers in this domain contented themselves largely with the investigation of the effects of various types of opotherapy on the most obvious symptom of diabetes, namely, glycosuria. Only recently has the work - or some of it - become more critical in the sense of adopting more fundamental criteria, such as the effect on glycemia and on the respiratory quotient.

Here, as in all such problems, it has taken much continued effort to eliminate irrelevant, interfering factors, which have vitiated results and invalidated researches; for example, many of the pancreatic extracts used have been of an acid reaction, regardless of the fact that this physical condition, per se, influences greatly the state of hepatic glycogen, and hence the glycosuria. Again, many investigators have selected one type of opotherapy (as injections or transfusions) to the exclusion of other types, and apparently at random, that is, without due consideration of the reasons for so choosing.

* Submitted for publication Aug. 13, 1914.

* From the Department of Experimental Surgery, Morris Institute of Medical Research of Michael Reese Hospital. 
Correlating the many researches, however, the influence of pancreatic opotherapy on carbohydrate metabolism has, at least in some of its aspects, been rather minutely investigated. In contrast, there are in the literature only casual references to the influence of organotherapy on the formation and excretion of ketone bodies, and it has been the intent of the present work to investigate this relation more precisely.

As it is particularly in the complex field of diabetes that progress has been so hampered and retarded by preconceived theories, it seemed best to attack each segment of the problem unprejudiced by any general, hypothetical concepts. Hence, all unproved assumptions as to an internal pancreatic secretion, its nature, or even its existence have been insistently avoided. Also a neutral ground as to the importance of the ketone bodies for the clinical picture of diabetes has been assumed. There is at present no certainty as to whether "acidosis" is a complication of diabetes, or an integral part of the deranged functioning, as to whether the ketones are the cause of coma diabeticum or merely harmless by-products of the essential vicious metabolism. Accordingly, in the introductory bibliographic interpretation given below I have sought to eliminate all unproved dogmas, and to keep within the bounds of objective data.

\section{HISTORICAL AND CRITICAL}

Any investigation of the influence of pancreatic organotherapy on ketogenesis must obviously take into account, at every step, the allied problem of the effect of such opotherapy on glycosuria and on the general constitutional condition; this because of the close relationship subsisting between carbohydrate metabolism and "acidosis." I shall accordingly, in conformity with the following schema, briefly review the past work along each of these lines:

1. Effect of pancreatic opotherapy on glycosuria and the general condition.

(a) Feeding.

(b) Injections.

(c) Transfusions and parabioses.

(d) Grafts and transplants.

2. Effect on ketoplasia and ketogenesis.

EFFECT OF PANCREATIC OPOTHERAPY ON GLYCOSURIA AND THE GENERAL CONDITION

(a) Feeding of Gland and Its Extracts and Ferments

When dogs suffering from chronic, pancreatic diabetes are fed with raw pancreas, the glycosuria increases three- or four-fold; cooked 
gland gives negative results. ${ }^{1}$ The feeding of raw muscle and other tissue extracts exerts a similar augmentative effect on the glycosuria. ${ }^{2}$

Fresh pancreas (of sheep, calf or fish) in human diabetes has given either negative results, sometimes accompanied by slight subjective (psychic) improvement, ${ }^{3}$ or else an actual increase of glycosuria. ${ }^{4}$ The feeding of pancreatin also causes greatly increased glycosuria. ${ }^{5}$

Positive results are few and questionable. Ausset ${ }^{6}$ claimed lowering of glycosuria and even complete "cessation of diabetes" in diabetic dogs and man fed on cooked pancreas. In one group of cases, however, namely, the diabetides of distinctly pancreatic type with deficient fat and protein absorption, there seems to be abundant evidence of improvement in absorption and general nutrition following exhibition of pankreon, ${ }^{7}$ or of raw sheep pancreas. ${ }^{8}$

As to the influence on carbohydrate tolerance in this group of cases, Wegele and Meyer claimed an improvement, while Mosenthal in his carefully controlled observations denies any effect. Pratt, Spooner and Murphy induced in dogs the chronic diabetes of slowly progressive pancreatic atrophy, with lowering of dextrose tolerance and markedly decreased absorption of fats and proteins. Raw sheep pancreas was then administered over prolonged periods. In general, fat and protein absorption were improved, and in one animal the carbohydrate tolerance was greatly increased. Even in this case, however, the tolerance could not always be raiseci; moreover, in other dogs this influence was slight and in a late case ${ }^{9}$ negligible.

With regard to the treatment of diabetes by feeding acid extracts of duodenal mucosa or secretin, a few authors ${ }^{11}$ have claimed improvement, but most observers report negative results. ${ }^{12}$ Altogether the destructive criticism of Pflüger ${ }^{13}$ and Leschke, ${ }^{14}$ which showed most such results to be the expression of fluctuations common to all nontotal diabetics, seems to be applicable also to the later results, but with the exception noted above - namely, the positive influence on digestion and assimilation in pancreatic diabetes. Moreover, lessened glycosuria when observed is almost certainly due at times to a toxic lessening of renal permeability, the hyperglycemia not being decreased (see below).

\section{(b) Injections of Pancreatic Extracts and Ferments}

Intraperitoneal injections of emulsions of fresh pancreas in depancreatized dogs sometimes cause marked drops in glycosuria. ${ }^{15}$ But all such effects are due to a peritoneal irritation with reflex decrease of renal permeability. ${ }^{16}$ No improvement results in human diabetes from intraperitoneal injection of emulsions. ${ }^{17}$ Repeated large doses given to guinea-pigs and depancreatized frogs by the peritoneal and also by the combined subcutaneous and peritoneal routes not only result in no 
improvement of the diabetes, but are actually very toxic and uniformly increase glycosuria. Extracts inactivated by heat give negative results. ${ }^{14}$

Subcutaneous injections of pancreas may cause marked drops of glycosuria in human diabetes, ${ }^{18}$ and in the pancreatic diabetes of dogs ${ }^{19}$ Certain pancreatic extracts given subcutaneously cause diminished glycosuria in the epinephrin - and phloridzin - diabetes of animals. ${ }^{20}$ But such reductions of glycosuria are always associated with general, constitutional depression or with decreased renal permeability, ${ }^{21}$ the latter accompanied by increase of blood-sugar. ${ }^{22}$ There is also abundant evidence that diabetes is not ameliorated in any of its aspects. Thus, subcttaneous injections of extracts give negative results in human diabetes. ${ }^{23}$ In depancreatized dogs they give similarly negative results, ${ }^{24}$ and even cause a toxic increase of glycosuria. ${ }^{25}$ Leschke $^{14}$ verified this for guinea-pigs and depancreatized frogs. Indeed, subcutaneous injections of extracts of almost any organ cause toxic effects and a glycosuria (liver, spleen, heart, kidneys, pancreas, skeletal muscle $\left.{ }^{26}\right)$.

Intravenous injections also give therapeutically disappointing results. Thus, Williamson ${ }^{17}$ observed no influence over human diabetes, and Hédon, ${ }^{27}$ working on diabetic dogs; observed no improvement, while his tables actually show a glycosuric effect. Zuelzer ${ }^{28}$ administered his "hormone" of dog pancreas intravenously to depancreatized dogs and human diabetics. The resulting temporary decreases in glycosuria and ketonuria are admittedly secondary to the marked constitutional (toxic) depression. ${ }^{29}$ Alcoholic extracts administered intravenously give negative results; aqueous extracts cause transient lowering of glycosuria and dextrose-nitrogen ratio, but this is interpreted as a toxic depressor action rather than as specific regulatory. ${ }^{30}$

It seemed at first that extracorporeal perfusions, while not strictly opotherapeutic, might throw light on the problem. Thus, the addition of pancreatic extracts to blood perfused through the beating heart caused a marked disappearance of dextrose, which was thought to be due to the "pancreatic hormone." 31 This view is now abandoned. ${ }^{32}$ The sugar disappears not through oxidation, but by polymerization. ${ }^{33}$ Other fallacies are also inherent in the perfusion methods as applied to pancreatic opotherapy. ${ }^{34}$ Thus slight changes in reaction affect the storing of glycogen $;^{35}$ also slight changes in the concentration of $\mathrm{K}$-ions influence the disappearance of sugar from the blood. ${ }^{36}$ When pancreatic extracts are added to the blood perfused through isolated surviving livers, there does not appear to result any increased deposit of glycogen or any diminished glucose production. ${ }^{37}$ 
Two recent researches are of especial importance because based on the realization that fluctuations in glycosuria are of manifold significance, owing to the complexity of the factors which may influence them and that the final test of a "hormone" will be the restoration of pancreatic function to the entire organism, the best criterion being conceived to be the respiratory quotient. Thus ${ }^{38}$ pancreatic extracts given intravenously and subcutaneously to depancreatized dogs exert no influence on the respiratory quotient. After large injections there is sometimes a temporary fall of glycosuria due to decreased renal permeability, but soon followed by a compensatory rise.

Feeding or injections of diastase probably have no relation to pancreatic opotherapy, since it is not a function of the pancreas to deliver diastatic ferment to the blood. ${ }^{39}$ Moreover, the lowered glycosuria sometimes following intravenous injection of diastase ${ }^{40}$ is certainly secondary to the general systemic depression. ${ }^{14}$

According to some observers there results an actual increase of glycosuria on intravenous or subcutaneous injections of diastase, ${ }^{41}$ or of pancreatic juice. ${ }^{42}$

\section{(c) Transfusions and Vascular Parabioses}

When pancreatized dogs receive transfusions of fresh blood from normal dogs their glycosuria is sometimes uninfluenced, ${ }^{43}$ but more often is temporarily decreased. ${ }^{41}$ Fresh, defibrinated blood gives the same result. ${ }^{45}$ The hyperglycemia is not reduced. ${ }^{46}$

Similar results follow the crossing of circulation between normal and diabetic dogs by vascular parabioses. This is true no matter what vessels are anastomosed, but the reduction of glycosuria is greatest when the blood passes from the pancreatic circulation of the normal into the systemic circulation of the diabetic dog.47 However, this reduction of glycosuria has no relation to specific opotherapy. It is due to a temporary, toxic decrease of renal permeability, as Hédon himself admits in his last papers. ${ }^{\star 8}$ It is associated with oliguria and albuminuria, and with general constitutional disturbances-fever, anorexia and marked depression. The hyperglycemia is either increased (normal dog) or not reduced (diabetic dog). Moreover, a few hours after such transfusion there occurs a compensatory rise in dextrosuria, balancing the temporary reduction. ${ }^{49}$

The introduction of foreign bloods and serums per se is partially responsible for these toxic phenomena. Thus in Hédon's experiments the normal dog became immediately glycosuric and hyperglycemic, and when two totally diabetic dogs were joined both developed oliguria and reduction of glycosuria, and both invariably died. Pancreatic extracts have been repeatedly shown to decrease renal permeability to 
dextrose, ${ }^{50}$ but Hédon's last experiments make it probable that the toxic effect on renal permeability is due to the foreign serums.

When the more fundamental criterion of respiratory quotient is invoked, it is found that the transfusion of large amounts of fresh, defibrinated blood, or whole blood, from normal to diabetic dog gives rise to no change in the respiratory quotient, and presumably no increase in the oxidative capacity of the organism. Crossed circulations are also negative in the same sense. ${ }^{38}$ A similar toxicity of transfusions for the human diabetic is strikingly shown by the case of Raulston and Woodyatt, ${ }^{51}$ who directly transfused blood from a normal man to his diabetic brother. The diet and metabolic data had been carefully controlled for months. The result was a marked (late) increase in dextrosutia, and in ketonuria. There was no evidence of improved carbohydrate utilization, and the authors believe blood transfusions to be definitely contra-indicated in severe diabetes.

With reference to the use of lymph Biedl, after reviewing the literature, ${ }^{52}$ concludes on the basis of original experiments that intravenous and subcutaneous injections tend to lower the dextrose-nitrogen ratio.

\section{(d) Grafts and Transplants}

The extirpation of all the pancreas except a small lobe of the processus uncinatus, with subcutaneous implantation of the latter, ${ }^{53}$ its vascular pedicle being preserved, is generally referred to as a "transplantation," "5ut is rather an incomplete pancreatectomy with dislocation of the remaining fragment. Rarely such a lobe lives and functionates after cutting of the vascular pedicle, through establishment of secondary vascularization from the local tissues. ${ }^{55}$ This amounts to an autotransplant, but is equivalent, from the point of view of organotherapy, merely to any incomplete pancreatectomy.

Many attempts at heterotransplantation and homotransplantation have failed. ${ }^{56}$ Carrel, $^{57}$ in his latest address, shows on general grounds that autotransplants of organs are often viable, homotransplants or heterotransplants practically never.

Autotransplants of part of the pancreas into the spleen, the rest of the pancreas being extirpated, have succeeded, as shown by their ability to prevent the total diabetes. These have been free $e^{58}$ or pedicled with subsequent severing of the vascular stalk. ${ }^{59}$ The undoubtedly successful functioning of such autotransplants without pedicle teaches us no more than Lombroso's original experiment.

These procedures seem directly comparable with the extirpation of the hypophysis and immediate reimplantation into the cerebral cortex, with prolongation of life and viability of the graft for over a month. 
In this case, too, the glandular deficiency is established; otherwise the autotransplant will probably not take. ${ }^{\text {it }}$

Forschbach ${ }^{61}$ united dogs parabiotically, bringing peritoneal cavities and homologous layers of the parietes into continuity. There was no vascular continuity, and hence this procedure is the equivalent, not of transfusion or of crossed circulation, but of transplantation. On extirpation of the pancreas of one, the ensuing glycosuria was slight and developed late. The normal dog developed a (toxic) glycosuria. The wounds healed well and no diabetic cachexia developed. When the animals were separated, the depancreatized dog soon died of infection or cachexia.

If the pancreas of a pregnant dog near term be removed no glycosuria develops; after delivery it becomes intense at once. ${ }^{62}$ Are these last two observations to be explained on the basis of internal secretion or of toxic effects on renal activity?

\section{Summary}

To summarize with reference to the effect on glycosuria, the general constitutional condition, and the carbohydrate oxidative power of the organism :

1. Fecding of fresh pancreas has usually been observed, both clinically and experimentally, either to have no effect on, or else actually to increase the glycosuria. This action is hardly specific for pancreas, being induced by many raw tissues. It is doubtful whether carbohydrate tolerance has ever been increased. Good effects as to increased absorption of fats and proteins and improvement of nutrition must be concerled. Unfortunately, glycosuria has been made, in all feeding experiments, almost the sole criterion of the influence on carbohydrato utilization.

2. When, after injections of extracts and emulsions, lessened glycosuria occurs, it is referable to general systemic depression or to decreased renal permeabilily. Intraperitoneal injections are absolutely fallacious, because of the renal reflex. Under many conditions there is even a markedly increased toxic glycosuria. Adjudged by the most reliable criterion (respiratory quotient) the effects on carbohydrate intermediate metabolism are nil.

Injections of enzymes (diastases) also cause a toxic increase of glycosuria, but sometimes a temporary decrease of glycosuria associated with systemic depression.

3. Transfusions and crossed circulations always have a toxic action. Sometimes the glycosuria is temporarily reduced, in which case there are either associated symptoms of general depression, or else evidence of reduced renal function (albuminuria, oliguria, later compensatory 
rise of glycosuria). Sometimes there is a toxic increase of glycosuria, of ketonuria, and of toxic products of protein catabolism. Hyperglycemia is not decreased. There is no rise in the respiratory quotient. The reaction is bad in every sense as to the general systemic effect.

4. The successful (auto-) transplants show merely what was known from Lombroso's original experiment, namely, that if a living, functioning fragment of the animal's own pancreas of sufficient size be present in the blood circuit, diabetic symptoms will be inhibited.

The parabioses (Forschbach) and the pregnancy experiments (Carlson) seem to be the equivalents, from the opotherapeutic point of view, of homotransplants. In each case there was established a pancreatic insufficiency of one animal, and an attempt to remedy this by supplying the products of the pancreas of another individual of the same species. It is noteworthy that in only these two of many researches was an oppcrtunity afforded, by virtue of the absence of vascular continuity, ${ }^{63}$ for intimate interchange (parallel to osmosis of crystalloids), without an actual mixing of foreign bloods or serums. And in these two researches we possibly have some evidence of the influence of a pancreatic hormone over the fundamental causative processes of diabetes. In Forschbach's experiments the reparative functions of the diabetic animal were good, which is much more significant than any reduction of glycosuria. Even here there is the possibility of a toxic reduction of glycosuria.

\section{Factors Influencing the Degree of Glycosuria}

It is evident that the degree of glycosuria observed in any given opotherapeutic experiment is a resultant of several opposing factors, some tending to increase, others to decrease it, and probably none to be interpreted as really therapeutic in the sense of exerting any curative influence on the underlying metabolic error of diabetes. Some are more in evidence on parenteral, others on enteral administration. It is possible to designate roughly some of these factors:

A. Lessening glycosuria.

(a) Toxic decrease of renal permeability. ${ }^{64}$

(b) Decrease of glycosuria associated with general constitutional depression (as obviously in Zuelzer's hormone work), comparable to the decrease of glycosuria and ketonuria observed in moribund diabetics.

(c) It has been definitely shown that acidity or alkalinity of the extract per se may exert a marked effect on glycosuria and on glycemia, through its influence on the state of hepatic glycogen. Administration of even dilute acids mobilizes hepatic glycogen, alkalies exerting the reverse effect. ${ }^{65}$ 
B. Increasing glycosuria.

(á) The opinion has very generally been held that the increased glycosuria observed on feeding of pancreas may be due to bettered absorption. especially of carbohydrates. ${ }^{06}$ That other factors are at work is shown by the fact (Sandmeyer) that even after decrease of daily rations of diabetic dogs by 50 per cent., the glycosuria increases on pancreatic feeding from three to tenfold.

$\left(b^{\prime}\right)$ There is certainly a toxic glycosuria, or perhaps several types. And it is sometimes, if not always, accompanied by hyperglycemia. Even the increased glycosuria of pancreatic feeding has been interpreted by some as toxic, rather than due to increased absorption, ${ }^{67}$ Reach having proved that it is not due to better digestion or assimilation. The toxic split products of proteins are held to be the responsible agents, and this seems probable, inasmuch as the feeding of various amino-acids to diabetic dogs (both depancreatized and phloridzinized) and human diabetics results in a toxic increase of glycosuria. ${ }^{68}$ The increased glycosuria of parenteral opotherapy is almost certainly toxic. Leschke ${ }^{14}$ believes enzymes (for instance, trypsin) to be the agent, but hints at the possibility of non-catalytic (chemical) toxins. ${ }^{69}$ It is possible that the glycosuria and the toxic (or lethal) phenomena have different agents.

As to the point of attack of such a glycogenic toxin, one can at present only speculate as to whether the action is through increased hepatic glycogenolysis (mobilization of glycogen), toxic lowering of the general tissue oxidative capacity, increased renal permeability, or some other mechanism.

After repeated large injections of gland extracts (pancreas, thyroid, liver, kidneys, etc.), there develop no micropathologic changes specific for the various extracts, but in all cases, parenchymatous degenerative hepatitis and nephritis with perivascular infiltrations, hyperplastic follicular splenitis and hyperplasia of lymph-nodes. ${ }^{70}$

$\left(c^{\prime}\right)$ Finally, as a possible explanation of increased glycosuria, Cohnheim and Klein $\uparrow$ note that the foods causing the greatest flow of pancreatic juice (raw meats) are the ones causing glycosuria. They suggest that the internal and external pancreatic secretions are likely to vary inversely as to their potency, and that hence the increase in external secretion will be correlated with a decrease in internal secretion, even to the point of producing glycosuria. Of course, this is speculative.

Historically it will be noted that really positive results of opotherapy have receded as the criteria have become more exacting. Attention was earlier focused on the glycosuria, and to a lesser extent

†. Cohnheim and Klee: Ztschr. f. physiol. Chem., 1912, lxxviii, 464. 
on the general clinical condition. Of late more stress is being given to the true indices of carbohydrate oxidative power, and in the near future even heavier demands will be made on any attempt to establish the claims of an opotherapy, in conformity with the growing tendency to discard the assumption that the disturbances of carbohydrate intermediary metabolism constitute the sole essence of the entity diabetes. ${ }^{11}$

\section{INFIUENCE OF PANCREATIC OPOTHERAPY ON KETOGENESIS}

Only a few isolated and conflicting observations are recorded in the literature. Salomon ${ }^{72}$ observed an increase of acetonuria after the use of pankreon in a case of pancreatic diabetes.

Sandmeyer ${ }^{73}$ observed in his chronic diabetic dogs that the feeding of race pancreas caused increase of glycosuria (see above) with appearance of acetone and diacetic acid. The latter was noted twice, ${ }^{74}$ and only on administration of raw pancreas. No quantitative determinations were made.

Zuelzer, ${ }^{29}$ 11sing the hormone referred to above, in depancreatinized dogs and moderately severe human diabetes, observed lessened "acidosis," as indicated by the color intensity of qualitative tests of urine. But Forschbach ${ }^{i 5}$ invalidates these conclusions just as he had their deductions as to decreased glycosuria (see above), on the ground of the general toxic depression. Moreover, he observed no decrease of ketonuria, even with the marked constitutional reaction.

Mosenthal, ${ }^{76}$ in a single case of human diabetes, probably of pancreatic type (displaying deficient fat and protein absorption, with large fatty stools and undigested meat fibers), found that on a regimen of raw sheep pancreas feeding, the urinary ammonia was greatly increased, for example, from about $2.2 \mathrm{gm}$. on ordinary diet to about $5.2 \mathrm{gm}$. after exhibition of pancreas, this rise being associated with a corresponding increase in ketonuria, the beta-oxybutyric acid rising from $2.2 \mathrm{gm}$. to $32.1 \mathrm{gm}$. Mosenthal's observations were clinical, and in a particularly severe case, ${ }^{7 \pi}$ it became necessary, on considerations of safety, to interfere with the experiment in such ways as to detract from the clear-cutness of the interpretation. Thus, the use of opotherapy had to be frequently interrupted; alkalies were administered from time to time; also there is some ambiguity as to the amounts of fat fed, and the influence of other food elements. This is not mentioned in a spirit of criticism, as the duty to the patient obviously had to take precedence of the research. The great interest in Mosenthal's report lies in the fact that the feeding of raw pancreas gave rise to tremendous ketonuria in a case of undoubted "pancreatic diabetes." Under the opotherapy there was, except for the (at times alarming) increase of ketogenesis, a marked general improvement, and certainly increased utilization of fats; thus "the stools changed from those 
typical of pancreatic disease to what appeared to be normal movements." He concludes that the increased ketogenesis is due to increased intestinal absorption of fats. He evidently believes (following most authors) that dogs totally pancreatic-diabetic excrete no ketones, and explains this on the basis of non-absorption of fat. This question is examined below.

Raulston and Woodyatt, ${ }^{51}$ in their clinical research described above, noted, on direct transfusion of blood from normal to diabetic man, a marked increase of ketonuria. The total beta-hydroxybutyric acid increased from $190 \mathrm{gm}$. for the five days preceding, to $273 \mathrm{gm}$. for the five days following. Their metabolic work seems perfectly controlled as to diet and other factors. Dakin and Dudley ${ }^{78}$ perfused dogs' liver with blood containing added substances, known from Embden's experiments to yield aceto-acetic acid freely under these conditions, as tyrosin, the sodic salts of butyric and homogentisinic acid. To this perfusing blood were then added fresh extracts of pancreas, or heated pancreatic extract of skeletal-muscle extract, all prepared by grinding the fresh tissues in water. No decrease in hepatic ketogenesis resulted. Their conclusion is that they have found no evidence that the pancreas furnishes an enzyme or hormone, the absence of which leads to acidosis in the diabetic animal.

\section{METHODS}

\section{A. CHOICE OF ANIMALS; ACIDOSIS IN DOGS}

In undertaking a research on "acidosis" the selection of an animal is a matter of great importance. In general diabetic work, the dog has been, of course, at once the most available and most useful. But where any consideration of ketogenesis is concerned, one must raise the question as to whether a carnivore is suitable, the opinion being somewhat widespread that there is some fundamental difference in the reaction of dogs and man to factors of ketone formation; there has been a good deal of skepticism as to whether "acidosis" is of the same nature in dogs, or, indeed, even as to its occurrence. If such doubts be well grounded, much experimental work will have to be revised.

Minkowski ${ }^{79}$ found that ketonuria does not always follow total pancreatectomy in dogs, and hence interpreted ketonuria as a complication of diabetes. Brugsch and Bamberg ${ }^{80}$ held that "acidosis" furnishes the essential difference between canine and human diabetes, extreme acidosis never occurring in depancreatized dogs, which invariably die of inanition rather than in coma. They attach great importance to this postulate, believing that a severe diabetes with pronounced acidosis is probably not a pancreatic diabetes.

Allard $^{81}$ and Minkowskis2 opposed this view, proving that in dogs totally depancreatized, acidosis is not rare. Five of Minkowski's dogs 
excreted large amounts of ketone bodies. Allard cites three cases of marked acetone excretion (from 2 to $3 \mathrm{gm}$. total acetone in dogs of 8 to $9 \mathrm{~kg}$.), moderate amounts of acetone, diacetic and beta-oxybutyric acid being demonstrated in many depancreatized dogs. Normal adult dogs on starvation show only traces. Both Allard and Minkowski describe cases of probable death in coma. This ketonuria of dogs has been abundantly confirmed. ${ }^{8 *}$ It is constant after total pancreatectomy. ${ }^{84}$

Large amounts of diacetic acid are formed in the surviving livers of depancreatized dogs, perfused with blood. ${ }^{85}$

On the basis of all these findings and of my own observations, I certainly disagree with Allen ${ }^{86}$ in his conclusion that "totally depancreatized dogs are generally free from ketonuria." I can affirm absolutely on the basis of my own experiments that totally depancreatized dogs alway's develop ketonuria. I can, however, confirm Allen's statement that they often give no ferric chlorid reaction when excreting large amounts of acetone. However, I have at some time or other in every such dog always found aceto-acetic acid by certain of the tests. ${ }^{87}$

With regard to the factors influencing ketonuria in dogs, it occurs in chronic diabetes (Sandmeyer ${ }^{33}$ ) as well as in the total type. It is also generally held that in dogs, ketonuria is not increased in starvation, but rather reduced; also is not lessened by utilization of carbohydrates; is augmented by excessive meat feeding, and hence runs parallel to nitrogen excretion. ${ }^{s s}$

These statements are in general true for adult dogs, but one should not conclude that dogs would hence be unsuitable for "acidosis" work. It is certain that in dogs, as in man, a lowered carbohydrate intermediate metabolism predisposes to acidosis. Marum's ${ }^{89}$ observation that in phloridzin diabetes of dogs acidosis occurs only after exhaustion of the glycogen stores proves this. While dextrose-feeding has but little influence on acidosis in the adult dog, starvation acidosis is readily induced in young ones. ${ }^{90}$ Glucose, injected intravenously, diminishes acetonuria in phloridzinized dogs. ${ }^{91}$ Hunger acidosis is interpreted as a carbohydrate deficiency acidosis. Adult normal dogs may show traces of acetone in hunger. ${ }^{92}$

Ehrmann $^{23}$ found young dogs, when undernourished, to be susceptible to his chemical, ketogenetic factors. He also observed enormous preagonal (inanition) development of ketones in diabetic dogs. Gigon $^{94}$ points out that allowance must be made for the fact that the carnivorous dog has accustomed itself to "metabolic tolerance" of carbohydrate withdrawal; also that, in consideration of its body weight, total acetone value of from 0.2 to $0.3 \mathrm{gm}$. per diem are very high. Von Noorden ${ }^{95}$ takes the same view with reference to acquired toler- 
ance toward carbohydrate withdrawal, and has often noted the same phenomenon clinically in human beings. He also points out that man often shows a high degree of ketonuria, even when fed such large quantities of carbohydrates (from 50 to $100 \mathrm{gm}$. per diem) as would promptly control starvation acidosis of a non-diabetic.

Again, if a dog be fed for a long period on much bread, and then be put suddenly on pure meat diet, strong acidosis develops. Heavy protein feeding has a ketogenetic influence on man also, even to the point of danger. ${ }^{96}$

We have, then, a marked parallelism between all these phenomena in man and dog, and from these researches and my own observations, I believe there is no basic difference between the acidosis of a diabetic dog and that of man.

\section{B. CHOICE OF TYPE OF DIABETES}

The question arises as to the form of diabetes most appropriate. As Macleod ${ }^{97}$ points out, there is practically but one form of permanent hyperglycemia, and, of special relevance to our problem, only one form of experimental diabetes "which can be considered as analogous with the severer forms of the disease in man," namely, that following total pancreatectomy. It also seems that Leschke's"s dictum, "In view of the intermittent character of the glycosurias, which arise through partial extirpation of the pancreas, no conclusions can be drawn as to the influence of any medicinal drug on glycosuria," applies equally well to an investigation of the effect of ketonuria. Certainly in view of the fluctuation known to occur in the glycosuria and ketonuria of partial pancreatectomy, the logical first phase of such an investigation is on the completely diabetic animal. ${ }^{99}$

\section{TECHNIC, OF PANCREATECTOMY}

Twenty-three extirpations were done essentially by the method used by Minkowski and Witzel, ${ }^{100}$ all the later ones by Hédon's technic ${ }^{101}$ in two stages, dislocating a lobe of the processus uncinatus amounting to about one-sixth to one-tenth the total volume of the pancreas, to a subcutaneous position, with preservation of the vascular pedicle, and, later, extirpation of this. Hedon ${ }^{101}$ is certainly correct in maintaining that failure to obtain the concomitant symptoms - as polyphagia, polyuria, wasting - and, he might have added, the dextrose-nitrogen ratio of 2.8 or above, is certainly due to incomplete extirpation. Of course, pyogenic infection will lower the dextrose-nitrogen ratio.

D. METHOD OF APPLICATION OF OPOTHERAPY

All parenteral routes have been rejected, in view of the following considerations : 
1. The complications attendant on these methods - as constitutional disturbances, with chills, fever, etc. - all inevitably associated with depression of general metabolism, and hence easily giving rise to erroneous deductions and conclusions.

2. The possibility that parenteral, and especially subcutaneous, administration may reproduce, more or less accurately, the toxic syndrome of "acute pancreatic poisoning," thus complicating the interpretation by introducing factors far removed from the physiologic norm, and hence not only having no relation to true opotherapy (which must seek to approximate physiologic conditions), but even tending to obscure any such associated specific action. ${ }^{102}$ Lattes $^{103}$ believes that activization and passage of the tryptic ferment into the blood are possibly responsible for these sudden metabolic deaths. ${ }^{104}$

3. Perfusions of isolated organs were discarded on the basis of such conclusions as that of Ringer and Fraenkel, ${ }^{105}$ who deplore the artificiality of this method and its departure from physiologic conditions. Verzar and Fejer too have given expression to very cogent reasons for mistrusting this method, at least where problems of general metabolism are at stake. The organism as a whole may comport itself quite differently from the isolated organ. ${ }^{106}$ Dakin and Dudley ${ }^{78}$ also show that such researches as have been already conducted along this line with pancreatic extracts are of doubtful interpretation.

\section{F. GENFIRAL EXPERIMENTAL PRECAUTIONS}

1. All dogs were discarded in which any postoperative suppuration or infection persisted. Any such process may lower glycosuria, and also undoubtedly disturb other factors. ${ }^{107}$

2 . The dogs used were females; not very large; especially not deep chested; not fat; weight about 6 to $8 \mathrm{~kg}$; adult, but not old ; free from disease, especially mange and distemper; best of all, animals immune to distemper through previous infection. In one series of nine I used a prophylactic vaccine furnished through the kindness of Dr. James W. Jobling and Dr. Carroll Bull, prepared by isolating the Bacillus bronchosepticus (Ferry ${ }^{108}$ ) from the blood of several actively distempered logs. Those animals which recovered from the effects of the powerful vaccine were apparently immune. All animals with gastrointestinal disorders were rejected.

3. Before the pancreatectomy the urine was examined at least two days for sugar, etc.

4. Before the total pancreatectomy (or the second stage of the Hédon) the dog was brought into approximate nitrogen equilibrium (metabolic cages).

I soon learned to avoid long preoperative confinement of animals to the cage, and, by the Hédon method, was able to feed the animals 
even on the day of the second operation. Preliminary starvation (necessary for the old Witzel technic) interferes with metabolic work.

\section{F. CHEMICAL AND ANALYTICAL METHODS}

1. Presence and nature of reducing bodies by Haines or Fehling; polariscope; fermentation; phenylozazones. Quantitative sugar by Bang ${ }^{109}$ later by new Benedict, ${ }^{110}$ often controlled by polariscope.

2. Ammonia nitrogen by Folin ;11 ammonia nitrogen plus amino nitrogen by Malfatti. ${ }^{112}$ Total nitrogen by Kjeldahl.

3. Aceto-acetic qualitative by ferric chlorid; also Hurtley's test ${ }^{113}$ and Ondrejovich. ${ }^{114}$ The ferric chlorid was almost invariably negative. Acetone qualitative by Langes'115 di-nitroprussid.

4. Quantitative "total acetone" by the Messinger-Huppert method $;^{116}$ also at times checked up by Neuberg's modification of Messinger's method; but the results tallied closely. I felt justified in using the easier "total acetone," rather than the more difficult betaoxybutryric acid determination, since Gigon ${ }^{117}$ has shown the constant relationship which subsists, in a given individual, between excretion of acetone and of beta-oxybutyric acid. Embden and Schmitz' warning ${ }^{118}$ to avoid drawing over ammonia or other bodies fixable by iodin was carefully heeded.

5. Hepatic glycogen was only twice determined, and only by the method of Pfliger. ${ }^{119}$ This omission was justifiable because $(a)$ the dextrose-nitrogen ratios indicated total diabetes; $(b)$ after the first ten or fifteen operations the extirpations were with certainty technically total; $(c)$ even on the assumption that small fragments or accessory pancreases had escaped observation in a few animals, the general tenor of the results is dependent not at all on the presence of a total diabetes. The conclusions are valid for a sezere or total diabetes. Several of the later experiments, indeed, as will be seen, purposely represent incomplete cxtirpations, with no glycosuria on meat diet.

In the two cases in which hepatic glycogen was determined, the figures showed a practically complete absence of all glycogen. In one (Protocol 5) a $186-\mathrm{gm}$. liver contained 0.12 per cent., or $0.22 \mathrm{gm}$. glycogen. In the other (Protocol 6) a 247 -gm. liver contained 0.08 per cent., or $0.197 \mathrm{gm}$. glycogen.

\section{G. GLUCOSE THRESHOLD IN DOGS}

The dextrose threshold of normal dogs is variable, but in general runs from $3 \mathrm{gm}$. per kilogram weight (Hofmeister's figures) up to from 11 to $16 \mathrm{gm}$. per kilogram weight (Pflüger's). Relation to other food taking is important, as when given alone the average tolerance is probably 4 or $5 \mathrm{gm}$. ; when given with other food, $10 \mathrm{gm}$. or over. ${ }^{120}$ 


\section{PROTOCOLS}

Adult normal dogs show no ketone-excretion on pancreas feeding, or, indeed, on any dietetic regimen. This was verified on several normal controls, observed carefully for many weeks. Thus the "total acetone" was determined on Dog 7 for a period of one month. During this time there were administered two heavy feedings of pancreas, with no rise in the total acetone figure, the latter showing, throughout the month, the usual variation of normal dogs, from 0.002 to $0.01 \mathrm{gm}$. per diem for animals of 5 to $12 \mathrm{~kg}$. weight. Since immature and adolescent animals were not used in these experiments, only adult controls were used.

With regard to the effects of starvation, adult dogs show no increase of "total acetone," even on prolonged starvation. Elias and Kolb" have already shown that young normal dogs respond to starvation by ketonuria.

Adult, totally diabetic dogs show no appreciable effect of starvation on acidosis, until the starvation has been prolonged to the point of inanition, which means absolute starvation for at least five or six days. This is illustrated by Protocols 1 and 2 .

\begin{tabular}{|c|c|c|c|}
\hline Date & $-1-100 \mathrm{~s}$ & Total Acetone & Weight \\
\hline June & Food & $\mathrm{gm}$ & $\mathrm{kg}$. \\
\hline $18-19$ & $400 \mathrm{gm}$. beef & .012 & 15.4 \\
\hline $19-20$ & None & .0167 & .... \\
\hline $20-21$ & None & .0366 & \\
\hline $21-2$ & 1 liter milk & .078 & 15.2 \\
\hline
\end{tabular}

PROTOCOL 2.-Dog 31.-Total Extirpation, March 14, 1913

Unable to retain any food after pancreatectomy. Water taken in moderate amounts.

$\begin{array}{ccc}\begin{array}{c}\text { Date } \\ \text { March }\end{array} & \begin{array}{c}\text { Total Acetone } \\ \text { gm. }\end{array} & \begin{array}{c}\text { Weight } \\ \text { kg. }\end{array} \\ 12-13 & .0021 & 4.2 \\ 13-14 & .0044 & \ldots \\ 14-15 & .0113 & \ldots \\ 15-16 & .0521 & \ldots \\ 16-17 & .0643 & 4.0 \\ 17-18 & .0517 & \ldots \\ 18-19 & .0608 & 3.8 \\ 19-20 & .0710 & \end{array}$

Lüthje ${ }^{121}$ also incidentally shows ${ }^{122}$ that there is very little starvation acidosis in adult, depancreatized dogs.

Protocols 1 and 2 serve to illustrate another general observation, namely, that after total pancreatectomy the total acetone figures always rise moderately, irrespective of feeding or of starvation. The figures for normal dogs vary between 0.002 and $0.01 \mathrm{gm}$. per diem for dogs of from 5 to $12 \mathrm{~kg}$. weight. After total extirpation these rise to from 0.01 to $0.09 \mathrm{gm}$. for dogs of this size. The increase is rather gradual 
and progressive, and will not go much above $0.09 \mathrm{gm}$. on mixed diets, or on starvation.

PRotocol 3.-Total Pancreatectomy (Second Stage) July 3, 1913, of

Dog 50, which Colld Retain Nothing but Water Until Death

$\begin{array}{ccc}\text { Date } & \text { Total Acetone } & \text { Weight } \\ \text { July } & \text { gm. } & \text { kg. } \\ 2-3 & .002 & 4.4 \\ 3-4 & .0078 & \ldots \\ 4-5 & .009 & \ldots \\ 5-6 & .038 & 4.2 \\ 6-7 & .0309 & \ldots \\ 7-8 & .077 & \ldots .8 \\ 8-9 & .472 & 3.8 \\ 9 & & \end{array}$

In the case of Dog 50 (Protocol 3), as occasionally, there was an immense preagonal increase. Preagonal decrease almost to the zero mark was sometimes observed.

We cannot doubt from the observations of Elias and $\mathrm{Kolb}^{92}$ on young, normal animals that if young, diabetic animals had been used, the diabetic acidosis would have increased under starvation.

Aside from such controls, the general plan of the experiment was to place animals of known weight on diets so chosen as to satisfy calorific requirements, and then to replace, for definite periods, a part or all the protein by isodynamic amounts of pancreas (or liver, etc.), noting the influence on ketone excretion. It soon became apparent that the matter of control diet (that is, the food regimen of the days on which no pancreas was given) was very important, if one were to avoid confusing results and fallacious deductions. Much time and many animals were lost in the slow working out of these considerations. The earlier experiments showed that high protein food of any sort in a diabetic animal exerts a decided ketogenetic influence. Hence the necessity arose of preceding the feeding of pancreas by a diet including some other protein isodynamically the equivalent of the pancreas to be fed. After preliminary essays of a basal mixed diet, it was soon thought best to use a straight protein diet of lean meat. This was suitable for the carnivorous dog, and, in the form of lean, hind shank of beef, possessed the additional advantage of permitting protein and nitrogen content to be easily controlled. Later, dextrose and fat were added to the basal diet in some of the experiments. In general, a moderate excess of protein food constituted the fundamental diet. $^{123}$

It became evident from the earlier experiments in which no quantitative determinations of ketones were made, the intensity of color reactions being relied on, that on a moderately high protein diet of lean beef after total pancreatectomy, ketonuria sometimes developed, but with moderate intensity and rapidity, while the reaction to pancreas feeding was prompt, and marked by extreme development of aceto- 
nuria. In Protocol 4, only the qualitative tests were invoked, but these were carefully done, and included, each day, the various modifications of the di-nitro-prussid-alkali test for acetone; and the Gerhardt (ferric chlorid), Hurtley ${ }^{113}$ and Ondrejovich ${ }^{114}$ (iodin) methods for acetoacetic acid. On the twelve control days preceding the extirpation there was never a trace of acetone or aceto-acetic acid demonstrable. After the pancreatectomy, on diets varying between beef or dextrose, or beef and dextrose, there were no demonstrable ketones, but on the third and fourth twenty-four-hour periods (postoperative) there developed, following the administration of raw beef pancreas in doses of $30 \mathrm{gm}$., a positive acetone test, and on the tenth period, following a dose of 125 gm., positive acetone and diacetic reactions. At these two periods the anmonia-amino (Malfatti) jumped up also, as usual in ketonuria, from 0.183 and $0.177 \mathrm{gm}$. to $0.42 \mathrm{gm}$. and to $0.438 \mathrm{gm}$.

Protocol 4 illustrates the same result.

\begin{tabular}{|c|c|c|c|c|}
\hline & PROTOCOL 4.-D & -IOTAL & N, Nov. & \\
\hline $\begin{array}{l}\text { Date } \\
\text { Nov. }\end{array}$ & Food & Acetone & Diacetic & $\begin{array}{l}\text { Weight } \\
\text { kg. }\end{array}$ \\
\hline $20-21$ & $400 \mathrm{gm}$. lean beef & 0 & 0 & 13.3 \\
\hline $21-22$ & $\left\{\begin{array}{rl}400 & \mathrm{gm} . \text { beef } \\
10 \mathrm{gm} . \text { dextrose }\end{array}\right.$ & 0 & 0 & $\cdots$ \\
\hline $\begin{array}{l}22-23 \\
23-24\end{array}$ & No food & 0 & 0 & $\ldots$ \\
\hline $23-24$ & $80 \mathrm{gm}$. beef & 0 & 0 & $12 ?$ \\
\hline $\begin{array}{l}24-25 \\
25-26\end{array}$ & $120 \mathrm{gm}$. beef & $\begin{array}{l}0 \\
0\end{array}$ & $\begin{array}{l}0 \\
0\end{array}$ & 13.2 \\
\hline $\begin{array}{l}25-20 \\
26-27\end{array}$ & $\begin{array}{l}200 \mathrm{gm} \text {. beet } \\
200 \mathrm{gm} \text {. raw beef }\end{array}$ & ++ & $\begin{array}{l}0 \\
+\end{array}$ & $\cdots$ \\
\hline $27-28$ & $\begin{array}{l}\text { pancreas } \\
200 \mathrm{gm} \text {. beef }\end{array}$ & 0 & 0 & 1.32 \\
\hline
\end{tabular}

Such results, diametrically the opposite of what I had anticipated, since I was not familiar with the literature of pancreatic opotherapy, were so striking that it was decided to investigate the matter by quantitative methods. Protocol 5 is a specimen. ${ }^{121}$

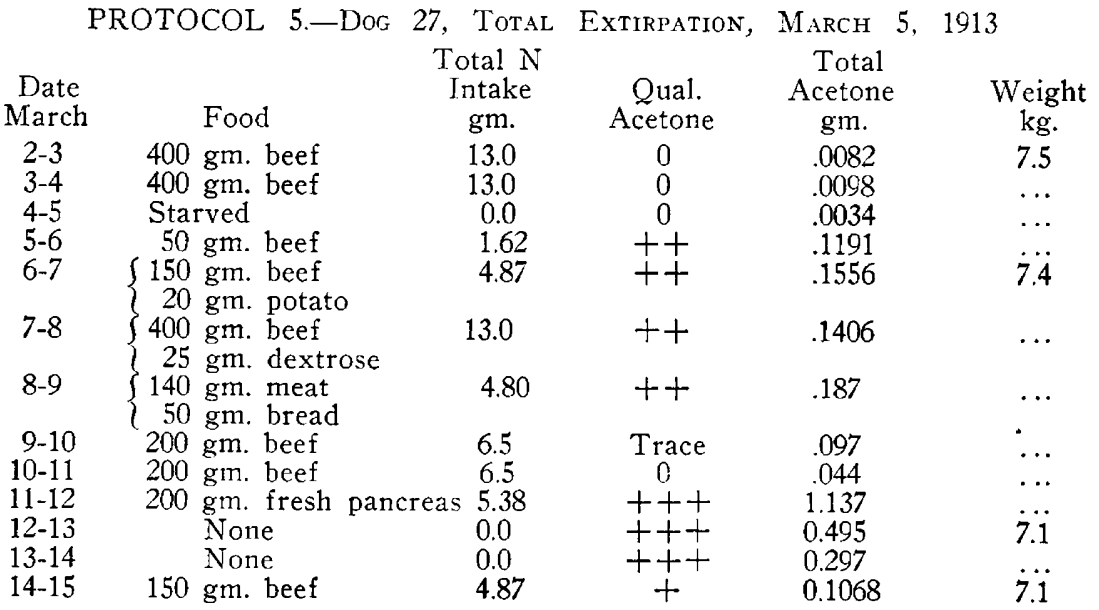


The dextrose-nitrogen ratio confirmed my operative assumption that the pancreatectomy was total.

This table, as many others, illustrates the fact that in total diabetes, ketonuria develops on feeding of high protein in any form of meat, but to a much greater extent on raw pancreas. Thus we find total acetones of from 0.1 to $0.4 \mathrm{gm}$. per diem (for dogs of from 6 to $12 \mathrm{~kg}$.) developing on beef diet, but of 0.3 to 0.6 to 1.0 on dynamogenetically equivalent amounts of raw pancreas. There is considerable individual variation in ketogenetic response; thus one animal may show as great a quantity of total acetone on beef feeding as another does on pancreas; hence it would be misleading to compare the quantitative results (or color reaction) of one dog on pancreas feeding with those of another on muscle feeding. In general, severely or totally diabetic dogs will not develop a qualitative acetone (color) reaction after several days' starvation or low diet or on a mixed diet not much above calorific requircments, but will rapidly develop it on high protein, and much more rapidly and intensely on protein-equivalent quantities of raw pancreas.

In some dogs, on moderate or high beef-muscle diet, the qualitative reaction is so marked that the change to pancreas does not render it more intense, inasmuch as it has already a maximum intensity for a color reaction. In such cases, however, the quantitative determinations, always show the difference plainly (Protocol 6).

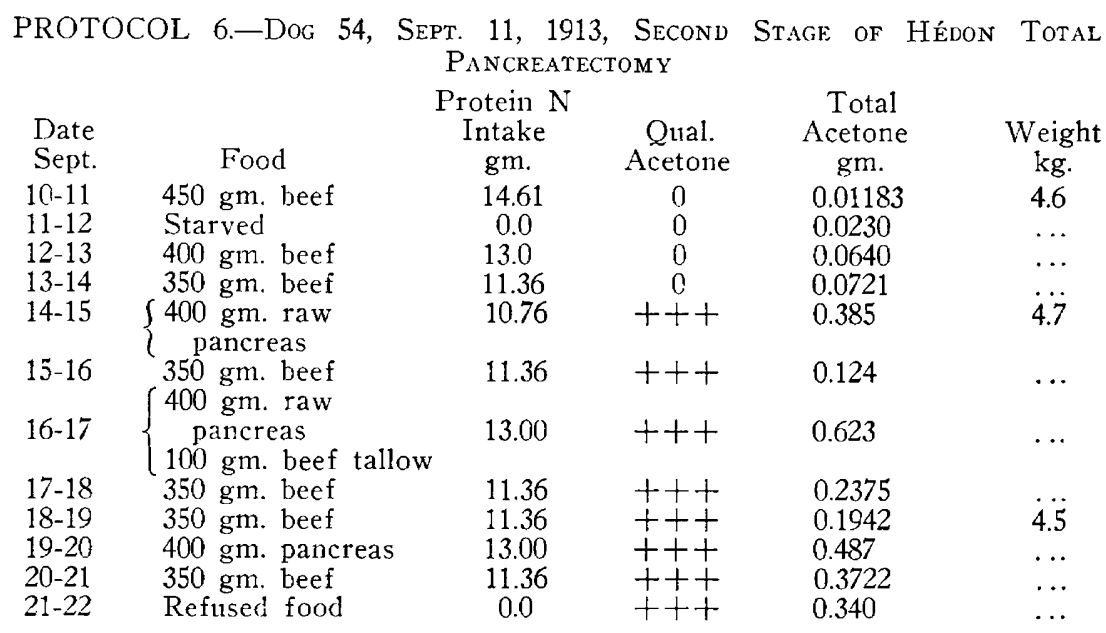

Here, after the maximum qualitative reaction had appeared after pancreas feeding, it remained essentially unchanged to the end. In general, the aceto-acetic reaction develops only if the acetonuria is intense; this applies especially to the ferric chlorid test, the more deli- 
cate Hurtley and Ondrejovich tests being positive with lesser degrees of acetonuria. ${ }^{12.5}$ The development of the aceto-acetic reaction as well as other points is illustrated in Protocol 7.

\begin{tabular}{|c|c|c|c|c|c|}
\hline PR & OCOL 7.-Dog 6 & $\begin{array}{l}\text { 67, Nov. 28, } \\
\text { PANCREAT }\end{array}$ & $\begin{array}{l}\text { 1913, SECOND } \\
\text { TOMY }\end{array}$ & Stage of & HÉDON \\
\hline $\begin{array}{l}\text { Date } \\
\text { Nov. }\end{array}$ & Food & $\begin{array}{c}\text { Protein } N \\
\text { Intake } \\
\text { gm. }\end{array}$ & $\begin{array}{l}\text { Qual. } \\
\text { Acetone }\end{array}$ & $\begin{array}{c}\text { Ferric } \\
\text { Chlorid } \\
\text { Reaction }\end{array}$ & $\begin{array}{l}\text { Weight } \\
\text { kg. }\end{array}$ \\
\hline $27-28$ & $350 \mathrm{gm}$. beef & 9.74 & 0.0026 & 0 & 9.2 \\
\hline $28-29$ & None & 0.0 & 0.0029 & 0 & \\
\hline $29-30$ & $350 \mathrm{gm}$. beef & 11.36 & 0.079 & 0 & $\ldots$ \\
\hline $30-1$ & 350 gm. beef & 11.36 & 0.104 & 0 & $\ldots$ \\
\hline $1-2$ & $\left\{\begin{array}{l}350 \mathrm{gm} \text {. beef } \\
20 \mathrm{gm} . \text { dextrose } \\
40 \mathrm{gm} . \text { fresh }\end{array}\right.$ & 11.36 & 0.0386 & 0 & $\ldots$ \\
\hline $2-3$ & $\left\{\begin{array}{l}\text { dog } \\
\text { pancreas } \\
200 \text { beef }\end{array}\right.$ & 7.59 & 0.638 & + & 9.3 \\
\hline $3-4$ & $\begin{array}{l}20 \text { dextrose } \\
350 \text { beef }\end{array}$ & 11.36 & 0.0603 & 0 & $\ldots$ \\
\hline & 20 dextrose & & & & \\
\hline 4-5 & $\begin{array}{l}350 \text { beef } \\
20 \text { dextrose } \\
80 \text { gm. fresh }\end{array}$ & 11.36 & 0.0504 & 0 & $\ldots$ \\
\hline $5-6$ & $\begin{array}{rl} & \text { pancreas } \\
300 & \mathrm{gm} . \text { beef } \\
20 \mathrm{gm} \text {. dextrose }\end{array}$ & 11.94 & 0.542 & + & 9.0 \\
\hline $6-7$ & Vomited all food & 0.0 & 0.420 & + & 8.7 \\
\hline $7-8$ & Vomited all food & 0.0 & 0.438 & + & \\
\hline $8-9$ & Vomited all food & 0.0 & 0.0752 & 0 & 8.4 \\
\hline
\end{tabular}

Dog 67 was totally diabetic, its dextrose-nitrogen on the 30th being 3.05. It was on a high protein diet, its weight having been about $9 \mathrm{~kg}$. and its daily lean meat ration from 200 to $350 \mathrm{gm}$. It illustrates well the action of raw pancreas, and shows that the latter is not cloaked or inhibited by concomitant feeding of dextrose. This and other protocols do, however, seem to indicate that heavy doses of pure dextrose tend to lessen acidosis even in dogs. Thus note that on the 30th and $1 \mathrm{st}$ the total acetone is $0.104 \mathrm{gm}$. on beef alone; on the next day it is 0.0386 on the same amount of beef plus $20 \mathrm{gm}$. sugar. Days 3-4 and 4-5 show the same influence, and I have several times noted this same effect. Compare Protocol 5 above, on days 6 to 9 .

Inasmuch as theoretical considerations would lead us to expect more from a hepatic than from a pancreatic organotherapy in diabetes, experiments were also conducted along this line, starting with the expectation that a lowering of dextrose-nitrogen ratio and of ketonuria would result. It was soon found, on the contrary, that glycosuria is not appreciably influenced (except incidentally by the concomitant variations in carbohydrate intake), and that raw liver is, as pancreas, ketogenetic, although not to so high a degree (Protocol 8). 
PRotocol 8.-Dog 17, Second Stage of Hédon Pancreatectomy, Done JAN. 6, 1913

\begin{tabular}{|c|c|c|c|c|}
\hline $\begin{array}{l}\text { Date } \\
\text { Jan. }\end{array}$ & Food & $\begin{array}{l}\text { rood N. } \\
\text { gm. }\end{array}$ & $\begin{array}{c}\text { Total Acetone } \\
\text { gm. }\end{array}$ & $\begin{array}{l}\text { Weight } \\
\text { kg. }\end{array}$ \\
\hline $5-6$ & $400 \mathrm{gm}$. beef & 13.0 & .0174 & 8.2 \\
\hline $6-7$ & $100 \mathrm{gm}$. beef & 3.25 & .058 & $\ldots$ \\
\hline $7-8$ & $400 \mathrm{gm}$. beef & 0.13 & .092 & $\ldots$ \\
\hline $8-9$ & $400 \mathrm{gm}$. beef liver & 13.05 & .364 & \\
\hline $9-10$ & $400 \mathrm{gm}$. liver & 13.05 & .467 & 8.1 \\
\hline $10-11$ & $400 \mathrm{gm}$. beef & 13.0 & .302 & $\ldots$ \\
\hline $11-12$ & $400 \mathrm{gm}$. beef & 13.0 & .1618 & $\ldots$ \\
\hline $12-13$ & $400 \mathrm{gm}$. beef & 13.0 & .283 & $\ldots$ \\
\hline $13-14$ & $300 \mathrm{gm}$. beef and & & & \\
\hline $14-15$ & $\begin{array}{l}\text { dextrose } 20 \mathrm{gm} . \\
\text { Beef pancreas } 350 \mathrm{gm} \text {, }\end{array}$ & $\begin{array}{l}9.74 \\
9.45\end{array}$ & $\begin{array}{l}.124 \\
.6023\end{array}$ & $\begin{array}{l}8.1 \\
8.0\end{array}$ \\
\hline $\begin{array}{l}15-16 \\
16-17 \\
17\end{array}$ & $\begin{array}{l}\text { Rejected all food } \\
\text { Rejected all food } \\
\text { Death }\end{array}$ & $\begin{array}{l}0.0 \\
0.0\end{array}$ & $\begin{array}{l}.1426 \\
.122\end{array}$ & 7.9 \\
\hline
\end{tabular}

It had seemed possible that beef muscle was less ketogenetic than beef pancreas on account of a possible inhibiting influence of the higher glycogen content of the former, but this explanation was rendered invalid by the results of liver-feeding, for liver possesses a much higher glycogen content than does muscle, yet it has decidedly greater ketogenetic properties. I also ascertained by direct experiment (Dog 53 ) that the feeding of $1 \mathrm{gm}$. of pure glycogen concomitantly with the pancreas did not inhibit in the least the ketogenetic action. This was, indeed, to be expected, inasmuch as the only way glycogen could exert such an effect would be by primary splitting to dextrose with absorption, and the protocols amply prove that even large amounts of dextrose $(20 \mathrm{gm}$.) given simultaneously with the pancreas do not exert a marked inhibitory influence on ketone formation. (See excerpt of Protocol 7, above, especially on dates 1 to 6.)

The feeding of fats simultaneously with pancreas gives rise to more marked increase in ketogenesis than that resulting from pancreas alone.

$\begin{array}{lccc} & \text { PROTOCOL } & \text { 9.-Dog 54, Total Pancreatectomy } \\ \text { Date } & \text { Total Acetone } & \text { Weight } \\ \text { Sept. } & \text { Food } & \text { gm. } & \text { kg. } \\ 13-14 & 400 \text { gm. beef } & .064 & \ldots .7 \\ 14-15 & 400 \text { gm. pancreas } & .385 & 4.7 \\ 16-17 & 400 \text { gm. pancreas } & .623 & \ldots \\ 19-20 & \text { 100 gm. tallow (beef) } & .487 & \ldots\end{array}$

Mosenthal ${ }^{76}$ explained the increased ketogenesis, which he observed in his case of severe diabetes on pancreatic opotherapy, as due to increased fat absorption. As proof he cites the fact that a phloridzinized dog (hence with normal absorption) develops ketonuria, while a totally diabetic dog (hence with fat absorption practically nil) shows none. This deduction is fallacious from two points of view: (a) In phloridzinized dogs ketonuria occurs, but only after the reserve gly- 
cogen depots have been exhausted $\left(\mathrm{Marum}^{89}\right)$. This shows a close relationship between ketogenesis and carbohydrate utilization, but no especial relation between ketogenesis and fat absorption. (b) Pancreatic diabetic dogs do develop ketosis. In the great majority of these experiments $I$ have avoided fat food, as a complicating factor, and hence I can be positive that increased intestinal absorption of fat is not the only or the main factor in heightened ketonuria after pancreas feeding.

After ketonuria has been once precipitated, especially in a severe form, as by repeated feedings of pancreas, there persists an increased sensitiveness to ketogenetic factors, so that the ketonuria tends to persist, though in lessened intensity, even under a diet non-ketogenetic. This may be due to a permanent, toxic damage (as of the liver) brought about by the first exhibition of pancreas.

Also in several experiments, afier a heavy ketonuria had been developed by pancreas feeding, it increased rapidly, the animal was very sick, vomited or refused all food, became comatose, sometimes developed edema, and died three or four days after the development of the intense ketonuria. In such cases the only positive necropsy findings were usually an enlarged liver, bright yellow in color and friable. Microscopically, such livers showed a high degree of fatty degeneration, almost to the point of complete replacement of the liver parenchyma by fat globules. None of the gastric ulcers or duodenal kinks described by Minkowski ${ }^{126}$ could be found in these cases of emesis and this is probably a toxic emesis.

\section{COMA DIABETICUM IN DOGS}

There is considerable dispute as to the occurrence in dogs and other animals of a true coma diabeticum. ${ }^{127}$ Ehrmann $^{128}$ discusses the differentiation between true coma and the allied states, and maintains that he obtains true coma in rabbits, by his sodium butyrates. In animals the signs and symptoms are naturally uncertain and difficult of interpretation, but if his objective criteria are valid, I certainly obtained coma in several dogs, and only in ones which had received pancreatic feeding. In those on ordinary carnivorous or mixed diet, death in inanition occurred the second or third week, but no definite coma. In a few there developed, after two or three administrations of pancreas, a narcosis-like sleep, with deep and slow inspirations and short forcible expirations. 'This came on early (even two or three days after the pancreatectomies) on heavy pancreas feeding, never except on pancreatic feeding, and was accompanied by great ketonuria, but usually (as in most other cases) by preagonal decrease of ketonuria to almost the zero mark. I have already referred to another type of death - the "acute pancreas death." 
One must differentiate this terminal syndrome of fatty toxic liver, ketonuria and coma from that of anesthesia liver degeneration. With the exception of the work done in the two months, December, 1912, and January, 1913, a fresh can of highest (anesthetic) purity ether has been opened for each pancreatectomy. But during that period, without the knowledge and contrary to the explicit order of the experimentor, left-over ether, kept in an ordinary bottle and exposed to sunlight, was used. The result was that practically every animal, fourteen in all, died on the fourth or fifth, or sometimes even the second or third days postoperative, displaying malaise, pernicious vomiting, and a comatose condition. The liver was always large and bright yellow. While ignorant of any toxic substances that might develop in ether under these circumstances, I feel assured that the extra burden put on the liver by pancreatectomy must in these cases have proved, in conjunction with some chemical toxins, too much for that organ. Many protocols and experiments demonstrates the slightness of the effect of an anesthesia of pure ether on ketogenesis. See, for example, the excerpt from Protocol 2. There is practically no postanesthetic rise in ketonuria in any case.

\section{EFFECT ON GLYCOSURIA}

In the earlier experiments it was thought that a reduction of glycosuria and a lowering of the dextrose-nitrogen ratio was observed on pancreatic feeding. But after a few experiments the fallacy became apparent. The food had been suddenly changed from a mixed diet containing considerable carbohydrate to one of pancreas - almost pure protein. Or where this was not the case, the attention had been focused on small chance variations in dextrosuria, incidental to all such experiments. It is certain that no lowering of glycosuria or of the dextrose-nitrogen ratio results from pancreatic feeding in totally, severely or mildly diabetic animals. I do not wish to be understood as questioning the results of Pratt, Spooner and others, with prolonged feeding of pancreas in milder types of diabetes.

\section{MILD DIABETES}

In several dogs, the size of the transplanted lobe was so regulated that a riabetes accompanied by a slight glycosuria or by a lowered threshold resulted. Thus Dog 74 (Protocol 10) displayed no glycosuria on a diet of meat, or of meat and starchy foods, or on $20 \mathrm{gm}$. dextrose with meals, but promptly developed glycosuria on $30 \mathrm{gm}$. dextrose, given with meals.

On pancreas feeding it showed slight increase of acetone, this rising from about 0.002 to 0.008 up to $0.009,0.01$ or even to 0.0974 . There was an increase of ammonia-amino during the twelve to twenty-four hours immediately following such feeding, as from $0.67 \mathrm{gm}$. up to 2. 3, 
or even $4.79 \mathrm{gm}$. The last figure was on feeding of $400 \mathrm{gm}$. pancreas. The preceding day, on a practically equivalent meal of $400 \mathrm{gm}$. raw beef, the Malfatti showed $0.863 \mathrm{gm}$. There was also the usual polyuria observed on pancreas feeding.

PROTOCOL 10.-Excerpt of Protocol of Dog 74, Operated on June 19. (Displayed No Glycosuria on Meat Diet June 20-June 24.)

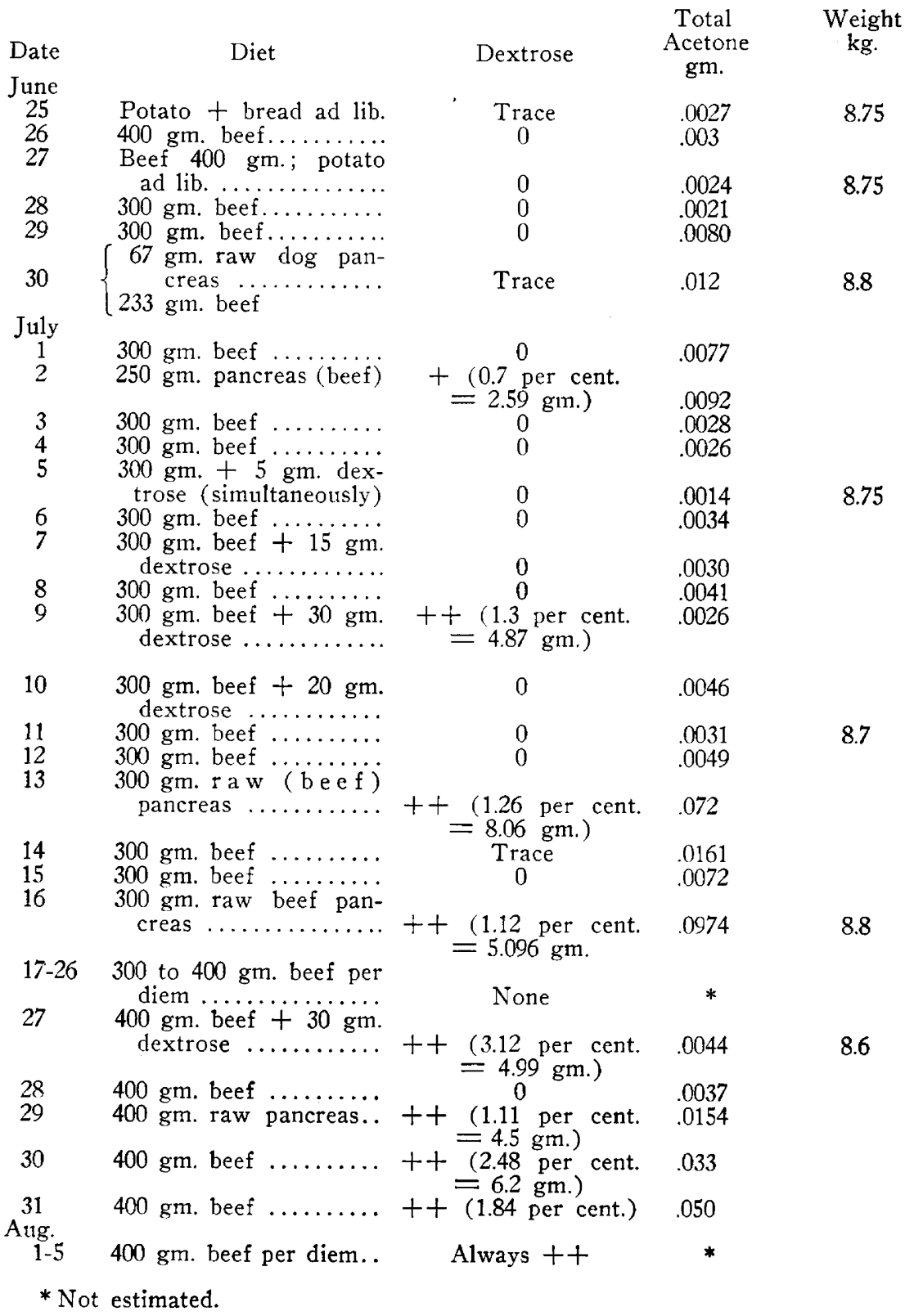


Most interesting of all, there developed a sharp and marked glycosuria, during the twenty-four hours following each pancreas feeding. This was present at no other time, except when over $25 \mathrm{gm}$. dextrose was given. We have invariably found, in dogs with greatly lowered tolerance but no actual glycosuria on meat diet, that the pancreas opotherapy precipitates glycosuria.

The positive dextrose findings were frequently checked up by polariscope and phenylhydrazin tests.

Similar findings as to the dextrose mobilizing power of pancreas by mouth were obtained on all animals which were mildly diabetic.

It will be noted in Protocol 10 that after the final pancreas feeding there was a persistent glycosuria. This has been observed twice. It seems probable that it falls in the same category as that increased sensitiveness of the diabetic organism to ketogenetic factors after repeated pancreatic opotherapy, referred to above. In all likelihood both represent a permanent toxic damage of liver or pancreas.

I am now engaged in determining whether or not the increased glycosurias of pancreatic opotherapy are accompanied by a hyperglycemia.

These influences of pancreas-feeding on ketonuria and glycosuria apply to fresh, raw' pancreas, and to raw pancreas kept on ice for several (at least four) days, but not to cooked pancreas.

Several subsidiary effects of pancreatic opotherapy were noted, but are already generally familiar. Thus the ammonia was increased concomitantly with the ketonuria. Amino-acid excretion was high in severe diabetes. My earlier determinations were unreliable, for I estimated the combined ammonia and amino nitrogen by the Malfatti method, and the ammonia by the Folin method, obtaining the amino nitrogen by subtraction. I was sometimes surprised to find the ammonia figure to be greater than the figure for ammonia plus amino. It was only late in this work that attention was called to the fallacy of using alizarin as an indicator. ${ }^{129}$ After this I verified the high amino nitrogen of the totally diabetic animal. ${ }^{130}$

\section{INTERPRETATION OF RESULTS}

Pancreatic feeding thus gives rise to increased ketonuria. Does that mean to increased ketogenesis? This is a pertinent question, because there is absolute clinical evidence that ketone excretion does not always run parallel to ketone formation. ${ }^{131}$ Those who champion the causal relation between ketones and coma diabeticum lay special emphasis on the toxicity of the non-eliminated fractions accumulating in the blood and tissues, this being true whether their toxicity is due 
simply to their acidity (Naunyn) or to a specific quality. Again, exhibition of alkalies certainly increases excretion of the bodies. ${ }^{132}$

But there is nothing in the behavior of our animals which would lead us to suspect that ketones are being generated and accumulated before the administration of pancreas, the latter simply increasing their excretion. In such case we should certainly have found at least some moderate increase in ketonuria prior to the opotherapy. In most of the experiments, the pancreas was given at an earlier period after pancreatectomy than one ever sees ketonuria developing on ordinary mixed or even raw beef diet. Moreover, there was no evidence that these dogs were suffering from ketone poisoning (if such an entity exists) prior to opotherapy. Also the toxic symptoms exhibited by the dogs appeared with, and increased in proportion to, the development of ketonuria. And in several of them there was what I interpreted as a real coma, with tremendous amounts of ketone bodies. This parallel development of ketonuria and toxic symptoms puts the burden of proof on those who would contend that the ketones were formed in the tissues early and excreted only under the influence of the pancreatic opotherapy. If one accepts the hypothesis of Embden and Michaud, ${ }^{133}$ according to which diacetic and beta-oxybutyric acids are physiologic, intermediary products or by-products of the formation of carbohydrates from fat, normally oxidizing to end-products before elimination, but appearing as such in the urine when, on carbohydrate deficiency, fat catabolism oversteps the bounds, then what I have just contended holds true, mutatis mutandis, so that even on this doctrine, there is no reason to believe that before opotherapy there were stored up in the tissues such unoxidized ketone bodies.

By what mechanism does pancreas feeding increase ketogenesis? Any attempt to answer this must take into account the factors which influence the production of acetone bodies ordinarily, that is, in the absence of pancreatic opotherapy.

With regard to their ultimate chemical source there is overwhelming accord that they largely arise in the course of intermediary metabolism, from the vitiated splitting of fats. ${ }^{134}$ However, one must concede the possible derivation of a portion of the ketones from protein. ${ }^{135}$

This being their ultimate source, what are the contributory or predisposing factors in ketogenesis?

First, and very obviously, diabetes. But the limitation of our knowledge in the field of pathophysiology is so great that the word "diabetes" can at present connote but little definite in this sense.

Second, and more concretely, increased ultilization of fats. ${ }^{136}$ Fats are, for the diabetic organism, ketogenetic.

Third, deficient utilization of carbohydrates. ${ }^{137}$ Of course, the diabetic organism furnishes the most conspicuous example of func- 
tional incapacity for handling carbohydrates. According to the interpretation now most current, there follows on this reduced consumption of sugars a compensatory increase of catabolism of body-fat and protein by way of response to calorific demand, such hypermetabolism then resulting in a false degradation of body fats, and possibly to a lesser extent of proteins (Landergren), ending in ketone formation. ${ }^{138}$

Other minor contributory factors must be mentioned. Thus young dogs (and human beings) are more susceptible to the action of any of the influences mentioned, especially carbohydrate deprivation. ${ }^{92}$ Also a lessened store of hepatic glycogen predisposes to ketogenesis. This is probably a specific phase under the general factor of lowered carbohydrate utilization; indeed, it may be the fundamental mechanism of the latter. ${ }^{89}$ The degree of acidosis bears no fixed relation to the degree of glycosuria. ${ }^{79}$ In phloridzinized dogs a preservation of the nitrogen equilibrium ensures freedom from acidosis; starvation precipitates it; ingestion of sugar prevents it. ${ }^{139}$ What light does this consideration of factors influencing ketogenesis throw on the mechanism by which pancreatic opotherapy increases it?

1. It is probable that feeding of pancreas may augment ketogenesis by determining increased absorption of fat. The latter has been proved to be ustally greatly impaired when the pancreas is badly diseased or partially extirpated, experimentally or for disease. ${ }^{140}$ The evidence, while not unanimous, points strongly to the conclusion that absorption and nutrition are considerably improved by raw pancreas feeding, and this seems to hold for the insufficiency arising from $(a)$ incomplete or complete extirpation, ${ }^{141}(b)$ supposedly complete exclusion of external pancreatic secretion from the intestine, ${ }^{112}$ and $(c)$ organic pancreatic disease. ${ }^{143}$

The question as to the precise nature of the mechanism through which the pancreas exerts this undeniable infuence on fat-absorption is too complex to be analyzed here except cursorily. That influence seems not to be attributable to any known direct effect or character of the external secretion, such as emulsifying power, alkaline content, lipolytic-enzyme content, or to any indirect effect exerted on associated digestive processes, as by controlling the secretion or activity of bile, or the intestinal motility. ${ }^{144}$ Lessened digestion of fats is not the solution, since it is certain that the splitting of food fats is but little or not at all impaired in pancreatic insufficiency. ${ }^{145}$ Yet there is considerable evidence that pancreatic juice is in some way necessary for absolutely normal fat resorption. ${ }^{14 i}$ As concerns the possible action of internal secretion, it is also doubtful whether the pancreas influences fat absorption through its effect on carbohydrate metabolism. Certainly any relation between hyperglycemia and vitiated absorption may be ruled 
out. ${ }^{147}$ Another allied concept, but of rather vague significance, is that lowered fat absorption is simply a part of the general depressed metabolism of severe diabetes (Allen). Finally, Lombroso has ably championed the view that a special pancreatic hormone exerts a control over the absorption of fat, and possibly its intermediary metabolism. ${ }^{148}$ In increase of fat absorption we have a partial explanation of the augmented ketogenesis on pancreas feeding. In those of our experiments in which fats were given concomitantly with pancreas, there was such an increased ketone excretion as to justify the deduction that this may be one etiologic factor, more especially in the mixed diet of the usual diabetic regimen. However, the results cannot be interpreted altogether along this line, because I have, in many experiments, avoided any possible absorption food fats.

2. The degree of protein absorption is a possible factor. This is certainly decreased in pancreatic insufficiency and improved on pancreatic feeding. ${ }^{149}$ In the removed pancreas (used for opotherapy) trypsinogen is speedily converted into trypsin. Thus, fed pancreas not only has a high protein content per se, but also may help in digestion and absorption of any other food protein. It is certain from the results of the present work that several of the raw protein foods (beef, pancreas, liver) are ketogenetic to the diabetic organism. But whether or not this is a property of the protein, as such, depends on the extent to which proteins are an ultimate chemical source of ketones. There is reason to believe that the rôle is inconsiderable (see above).

3. Almost certainly the ketogenetic properties under discussion are toxic, probably owing to autolytic substances which are normally destroyed by the pancreas (detoxicating theory of pancreatic function). This is along the line of Reach's ${ }^{150}$ interpretation of the increased glycosuria and hyperglycemia after feeding of raw meats. Such glycogenetic and ketogenetic toxins are probably non-specific for pancreatic tissue, but present in greater quantity in pancreas, or else in a more potent form than in liver or in muscle tissue. They may be conceived of as exerting their ketogenetic influence in many different ways, but most plausibly by deranging the hepatic function. ${ }^{151}$

4. Could the increased ketogenesis be secondary to decreased utilization of carbohydrates? Probably not. For the overwhelming evidence is that opotherapy does not decrease the burning of sugar (see above). Moreover, most of my animals were totally diabetic, and hence already oxidizing a minimum of carbohydrates. ${ }^{152}$ Of course, those authors certainly go too far who deny any controlling influence of carbohydrate metabolism on ketone-formation in carnivora. Marum's ${ }^{89}$ important observation that in phloridzinized dogs acidosis occurs only after the reserve glycogen has been consumed proves this. But it is 
undoubtedly true that the correlation between acidosis and carbohydrate non-utilization is not nearly so close in the dog as in man. The adult dog is "accustomed" (von Noorden) to bear carbohydrate deprivation without reacting by acidosis. Allard ${ }^{\text {s1 }}$ has specifically shown that the dog does not readily respond to low carbohydrate by acidosis. My experiments repeatedly show that feeding of dextrose in heavy doses does not lessen the acidosis appreciably, once it is developed. Apropos of this possible relation of acidosis to depressed sugar metabolism, it occurred to me near the close of these experiments that the glycogen present in the skeletal muscle might be responsible for the lesser ketogenetic activity of fed muscle, as compared with that of pancreas. But the two experiments on liver-feeding showed that this may be ruled out as a factor, for the liver of a normal dog has a high glycogen content, and yet the ketogenetic response was almost as marked as in the case of pancreas. Pancreas contains only a trace of glycogen. Feeding of glycogen alone gave rise to no increase or decrease of acetone excretion, as was indeed to be anticipated, inasmuch as glycogen, like starch, must be split to disaccharids and monosaccharids before absorption; and we know the latter are not as markedly antiketogenetic in carnivora as in man.

5. Finally, it seems conceivable, although not probable, that, in pancreatic opotherapy, enzymes are introduced which stimulate the tendency to ketone formation already present; or expressed more precisely, catalytics, which accelerate the mass-action tendency already inherent in a diabetic organism to vitiated catabolism of fats (perhaps also of proteins), with consequent ketogenesis. I here refer to ferment action on intermediary metabolism, for Reach ${ }^{150}$ has already excluded the local action of external secretion ferments in increasing fat absorption. There is also the possibility that this opotherapy acts by mobiliz ing tissue fats, giving rise to increased intermediate metabolism of endogenous fat; the vicious splitting of such fats in the totally diabetic organism would then give rise with certainty to ketones.

\section{SUMMARY}

In the severe or total pancreatic diabetes of dogs, ketonuria of sufficient intensity to be demonstrable by the qualitative tests always develops provided the animal survives several days, and is on a diet covering its calorific requirements.

The "total acetone" figures for adult normal dogs of from 5 to $12 \mathrm{~kg}$. weight run about 0.005 to $0.01 \mathrm{gm}$. per diem.

After total or near total pancreatectomy and on complete starvation (except for water), there is a slight gradual increase to about $0.01 \mathrm{gm}$. up to $0.09 \mathrm{gm}$. per diem. 
By judicious administration of a low calorie mixed diet after pancreatectomy the total acetone figures may be kept down to about the latter limits.

Heavy protein diets of any sort exert a ketogenetic influence on the diabetic organism. Thus the feeding of an exclusive protein diet of lean beef for several days invariably precipitates a ketonuria appreciable by ordinary qualitative tests, the total acetone going up to 0.1 to even $0.4 \mathrm{gm}$.

On dynamogenetically equivalent amounts of raw pancreas the total acetone always increases greatly to 0.5 to 0.7 or even over $0.1 \mathrm{gm}$. per diem, which represents tremendous amounts for dogs; the color reactions have a maximum intensity. Such increases occur on a single feeding of pancreas. The feeding of raw liver is responded to by a greater ketonuria ( 0.3 to $0.4 \mathrm{gm}$.) than that following muscle feeding, but not nearly so marked as the reaction after pancreas. These differences were proved to be not due to variations in protein content or in glycogen content.

I doubt whether this ketogenetic influence of pancreatic opotherapy is altogether specific. Yet, in view of the consideration that it is so much greater for pancreas than for other representative protein foods we cannot deny the possibility of its being specific.

As to the mechanism of its action, I have shown that it is not referable to increased absorption of protein or of fats, although both these are factors in additional increase of ketogenesis. It may be associated with increased intermediate metabolism of body-fat; I have not attempted to prove this. It is probably a toxic action, comparable to the increased glycosuria demonstrated by Reach ${ }^{150}$ on pancreas feeding. Doubtless such toxic influences are largely directed toward the hepatic functions.

If views as to the nature of diabetic acidosis be classified into two groups (Allen ${ }^{153}$ ), namely $(a)$ those maintaining that this is a condition sui generis (von Noorden and others) and $(b)$ those holding it to be due solely to carbohydrate deficiency (Landergren, Forssner, Gigon), then I believe the present experiments tend strongly to show that "acidosis" in dogs may vary independently of the status of carbohydrate ingestion and metabolism.

\section{CONCLUSION}

With reference to the practical aspect of pancreatic organotherapy, Allen" remarks, "All authorities are agreed upon the failure of pan- 
creatic opotherapy in diabetes. The attempts are continued because of the strong theoretical inducements."

On the contrary, after ruling out all doubtful cases and false interpretations, there seem to be a few exceptions to this dictum, namely, cases of diabetes associated with deranged absorption of fats and proteins; and it is only the administration of unheated pancreatic emulsion or extracts, including pankreon, by feeding which seems to be of avail here. Moreover, both glycosuria and acidosis are increased, and yet, under careful control, this therapy seems to have been, in selected cases, of some benefit. ${ }^{154}$

With reference to their theoretical bearing, these negative results of organotherapy have been repeatedly invoked by the opponents of the doctrine of pancreatic internal secretion (Pflüger, Leschke and others) as effectually negating that hypothesis. But it is metaphysically speaking, one thing not to have proved a doctrine, quite a different thing to have disproved it. We may possibly agree with Hédon's ${ }^{27}$ aphorism that the existence of a pancreatic internal secretion will only then have been demonstrated when it shall have been possible to check diabetes of a depancreatized dog by some form of pancreatic opotherapy. But we can never consider it disproved until the cause of the negative results has been fathomed; as Pflüger remarks, "Negative proofs in themselves have no final force unless the proof shows why they are negative."155

Moreover, aside from the philosophical aspect, it is possible to assign several specific reasons for anticipating such negative results. Thus, as Verzar and Fejer ${ }^{156}$ aptly remark, "A negative result can be occasioned by various other causes. Thus to mention only one possibility, the amount supplied in this manner to a body from which the pancreas hormone has entirely vanished may be too small to reach a concentration sufficient for the oxidation of sugar."

We have always the undisputed fact staring us in the face that when the pancreas is extirpated a total diabetes is precipitated; and that when a small part of that organ is left in the blood circuit, but otherwise separated as to all organic continuity (even nervous) from the rest of the animal, the latter is yet preserved from diabetes (Lombroso). Biedl1:i7 is justified in contending that "the entire data on pancreas diabetes . . . testifies decidedly that here an internal secretion of the pancreas is lacking which normally plays a decisive rôle in carbohydrate metabolism."

I wish to express thanks to Dr. R. R. Bensley of the University of Chicago, who kindly read this manuscript and tendered many suggestions; also to Mrs. Margaret Kirk, for constant assistance in the operative work. 


\section{REFERENCES}

1. Sandmeyer: Ztschr. f. Biol,, 1895, xxxi, 12. Lüthje: Deutsch. Arch. f. klin. Med., 1904, 1xxix, 498. Reach: Biochem Ztschr., 1911, xxxiii, 436.

2. Reach: Biochem. Ztschr., 1911, xxxiii, 436. Allen: Glycosuria and Diabetes, Boston, 1913.

3. Mackenzie: Brit. Med. Jour., 1893, p. 63. Willis: Ibid., 1893, p. 1265. Sibley: Ibid., 1893, p. 579. Williamson: Practitioner, London, 1901, p. 417. Rennie and Fraser: Biochem. Jour., 1907, ii, 7. Pratt, J. H.: The Relation of the Pancreas to Diabetes, Jour. Am. Med. Assn., 1910, lv, 2115.

4. Wood: Brit. Med. Jour., 1893, p. 64. White: Ibid., 1893, p. 452.

5. Marshall: Brit. Med. Jour., 1893, p. 743.

6. Ausset: Sem. méd., 1895, xv, 376.

7. Wegele: Fortschr. d. Med., 1902, xx, 313. Meyer, E.: Ztschr. f. exper. Path. u. Therap., 1906, iii, 58.

8. Mosenthal, H. O.: A Case of Pancreatic Diabetes Mellitus, The Archives Int. Med., 1912, ix, 339. Allen: Glycosuria and Diabetes, Boston, 1913, p. 996.

9. Pratt, J. H., and Spooner, L. H.: A Study of the Internal Function of the Pancreas in Carbohydrate Metabolism, The Archives Int. Med., 1911, vii, 665. Pratt, J. H.: The Internal Function of the Pancreas, Jour. Am. Med. Assn., 1912, lix, 324. Pratt and Murphy: Jour. Exper. Med., 1913, xvii, 252.

11. Moore, Edie and Abram: Biochem. Jour., 1906, i, 28, 446. Crofton: Lancet, London, 1909, i, 607.

12. Dakin and Ransom: Jour. Biol. Chem., 1907, ii, 305. Bainbridge and Beddard: Biochem: Jour., 1906, i, 429. Foster: Med. Klin., 1907, p. 446.

13. Pflüger: Arch. f. d. ges. Physiol., 1907, cxviii, 267.

14. Leschke: Arch. f. Anat. u. Physiol. (Rubner's), 1910, Phys. Abt., p. 401. 15. Capparelli: Biol. Centralbl., 1892, xii, 606.

16. Von Fürth and Schwarz: Biochem. Ztschr., 1911, xxxi, 114. De Meyer: Arch. internat. de physiol., 1909, viii, 121.

17. Williamson: Practitioner, London, 1901, p. 417.

18. Battistini: Therap. Monatschr., 1893, p. 494.

19. Vanni : Arch. ital. di clin. med., 1894, p. 157.

20. Vahlen: Zentralbl. f. Physiol., 1908, xxii, 202.

21. Pflüger: Arch. f. d. ges. Physiol., 1907, cxviii, 277. Leschke: (Footnote 14). Minkowski: Arch. f. exper. Path. u. Pharmakol., 1893, xxxi, 85. Von Fürth and Schwarz: Biochem. Ztschr., 1911, xxxi, 114. De Meyer: Arch. internat. de physiol., 1909, viii, 121.

22. Scott: Proc. Soc. Exper. Biol. and Med., 1913, x, 101.

23. White: Brit. Med. Jour., 1893, p. 452.

24. Tiberti and Franchetti: Arch. ital. de biol., 1909, li, 127.

25. Minkowski: Arch. f. exper. Path. u. Pharmakol., 1893, xxxi, 85. Hédon: Travaux de physiologie, Paris, 1898, p. 133, cited by Pflüger: Arch. f. d. ges. Physiol., 1907, cxviii, 271.

26. Lépine and Boulud: Compt. rend. Acad. d. sc., 1906, cxliii, 949, cited by Allen: Glycosuria and Diabetes, Boston, 1913. Allen: Glycosuria and Diabetes, p. 817 .

27. Hédon: Travaux de physiologie, Paris, 1898, p. 133, cited by Pflüger: Arch. f. d. ges. Physiol., 1907, cxviii, 271.

28. Zuelzer: Ztschr. f. exper. Path. u. Therap., 1908, v, 307. Zuelzer, Dohrn and Marxer: Deutsch. med. Wchnschr., 1908, xxxii, 1380.

29. Forschbach: Deutsch. med. Wchnschr., 1909, xxxv, 2053. Leschke: (Footnote 14).

30. Scott, E. L.: Am. Jour. Physiol., 1912, xxix, 306.

31. Knowlton and Starling: Jour. Physiol., 1912, xlv, 146. McLean and Smedley: Ibid., 1913, p. 470.

32. Patterson and Starling: Jour. Physiol., 1913, xlvii, 135.

33. Levene and Meyer: Jour. Biol. Chem., 1911, ix, 97. Murlin and Kramer: Ibid., 1913, xv, 365 . 
34. Murlin and Kramer: Jour. Biol. Chem., 1913, xv, 365.

35. Elias: Biochem. Ztschr., 1913, xlviii, 120.

36. Loewi: München. med. Wchnschr., 1913, xiii, 690.

37. Paderi: Arch. d. farmacol. speriment., 1913, xvi, 54. Barrenscheen: Biochem. Ztschr., 1914, 1viii, 277.

38. Murlin and Kramer: (Footnote 34). Verzar and Fejer: Biochem. Ztschr., 1913, liii, 140.

39. Leschke: (Footnote 14). Ehrmann and Wohlgemuth: Biochem. Zentralbl., 1909, 1x, 381.

40. Kussmaul: Arch. f. klin. Med., 1874, xiv, 435, cited by Leschke (Footnote 14 ).

41. Hildebrand: Arch. f. path. Anat., 1893, cxxxi, 30. Rosenberger: Deutsch. Aerzteztg., 1902, cited by Leschke (Footnote 14).

42. Pariset: Compt. rend. Soc. de biol., 1906, p. 64.

43. Alexander and Ehrmann: Ztschr. f. exper. Path. u. Therap., 1908, v, 367. Allen: Glycosuria and Diabetes, Boston, 1913, p. 822.

44. Hess: München. med. Wchnschr., 1902, p. 1449. Lépine: Compt. rend. Soc. de Biol., 1903, p. 1288. Le diabète sucré, 1909, p. 363.

45. Drennan: Am. Jour. Physiol., 1911, xxviii, 396.

46. Lépine: Le diabète sucré, 1909, p. 363.

47. Hédon: Compt. rend. Soc. de Biol., 1909, 1xvi, 621. Ibid., 1909, 1xvi, 699.

Ibid., 1909, 1xvii, 792; Arch. internat. de physiol., 1910, p. 192; Rev. de méd., 1910, xxx, 617. Arch. internat. de physiol., 1910, x, 350. Compt. rend. Soc. de Biol., 1910, Ixviii, 341. Ibid., 1911, Ixxi, 124. Arch. internat. de physiol., 1911, x, 350. Compt. rend. Soc. de biol., 1912, 1xxii, 584. Arch. internat. de physiol., 1913, xiii, 4; Compt. rend. Soc. de biol., 1913, lxxiv, 238.

48. "But it is very probable that this phenomenon is due above all to a modification of the permeability of the kidney caused by the foreign blood" (mais il est fort probable que ce phénomène est dû surtout à une modification de la perméabilité rénale par le sang étranger).

49. Hédon: (Footnote 47). Raulston and Woodyatt: (Footnote 51).

50. De Meyer: Arch. internat. de physiol., 1909, viii, 121. Vahlen: Ztschr. f. physiol. Chem., 1909, lix, 194. Bayer: Ergebn. d. allg. Path. u. path. Anat., 1910, xiv, 1. Von Fürth and Schwarz: Biochem. Ztschr., 1911, xxxi, 114.

51. Raulston, B. O., and Woodyatt, R. T.: Blood Transfusion in Diabetes Mellitus, Jour. Am. Med. Assn., 1914, 1xii, 996.

52. Bied1: Innere Sekretion, 1913, Ed. 2, Part 2, p. 360.

53. Thiroloix: Le diabète pancréatique, thèse de Paris, 1892. Minkowski Arch. f. exper. Path. u. Pharmakol., 1893, xxxi, 85.

54. Biedl: Innere Sekretion, 1913, p. 359.

55. Thiroloix: (Footnote 53). Hédon: (Footnote 47). Lombroso: Arch. di farm., 1910, ix, 446.

56. Thus, Williams: Brit. Med. Jour., 1894, p. 1303. Pflüger: (Footnote 13).

57. Carrel: The Transplantation of Organs, address before the Fourth Congress of the International Society of Surgery, New York, April, 1914.

58. Martina: Deutsch. med. Wchnschr., 1908, xxxiv, 45. Hédon: Compt. rend. Soc. de biol., 1910, 1xviii, 341.

59. Pratt and Murphy: Jour. Exper. Med., 1913, xvii, 252.

60. Halsted: Jour. Exper. Med., 1909, xi, 175. Crowe, Cushing and Homans: Quart. Jour. Exper. Physiol., 1909, ii, 389, cited by Cushing. Cushing: The Pituitary Body and Its Disorders, Philadelphia, Lippincott, 1912, p. 320.

61. Forschbach: Deutsch. med. Wchnschr., 1908, xxxiv, 910; Arch. f. exper. Path. u. Pharmakol., 1909, 1x, 131.

62. Carlson and Drennan: Am. Jour. Physiol., 1911, xxviii, 397. Carlson, Orr and Jones: Jour. Biol. Chem., 1914, p. 19. Allen: Glycosuria and Diabetes, p. 829 . 
63. Demonstrated for parabioses of the Forschbach type by many workers (Allen, Glycosuria and Diabetes, p. 824). Organic individuality of placental and fetal circulation is admitted by all anatomists.

64. De Meyer: Arch. internat. de physiol., 1909, viii, 121. Vahlen: Ztschr. f. physiol. Chem., 1909, lix, 194. Bayer: Ergebn. d. allg. Path. u. path. Anat., 1910, xiv, 1. Wohlgemuth: Berl. klin. Wchnschr., 1913, p. 339. Von Fürth and Schwarz: Biochem. Ztschr., 1911, xxxi, 114.

65. Elias: (Footnote 35). Nishi: Arch. f. exper. Path. u. Pharmakol., 1910, 1xii, 170. Macleod: Diabetes, 1913. Elias and Kolb: Biochem. Ztschr., 1913, lii, 331 .

66. Sandmeyer: Ztschr. f. Biol., 1895, xxxi, 12. Minkowski: Berl. klin. Wchnschr., 1890, xxvii, 333.

67. Lüthje: Deutsch. Arch. f. klin. Med., 1904, 1xxix, 498. Reach: Biochem. Ztschr., 1911, xxxiii, 436. Leschke: (Footnote 14),

68. Nebelthau: München. med. Wchnschr., 1902, lxxix, 917. Lüthje: (Footnote 67). Mohr: Ztschr. f. klin. Med., 1ii, 337: iv, 1910. Kraus: Berl. klin. Wchnschr., 1904, xli, 4.

69. Autolytic decomposition products ("Zersetzung's autolytische Produkte," p. 435).

70. Ghedini: Centralbl. f. Bakteriol., 1903, xxxiv, 721.

71. Galambos and Tausz: Ztschr. f. klin. Med., 1913, 1xxvii, 14. Pribram and Löwy: Ibid., 1913, 1xxvii, 392, Hougounenq and Morel: Du coma diabètique, symposium, Sem. méd., 1911, No. 43, p. 505. Labbé: Ibid., 1911, p. 506.

72. Salomon: Berl. klin. Wchnschr., 1902, xxxix, 45.

73. Sandmeyer: Ztschr. f. Biol., 1895, xxxi, 12.

74. Sandmeyer: Ztschr. f. Biol., 1895, xxxi, Table II, p. 40.

75. Forschbach: Deutsch. med. Wchnschr., 1909, xxxv, 2053.

76. Mosenthal, H. O.: A Case of Pancreatic Diabetes Mellitus, The Archives INT. Med., 1912, iv, 339.

77. See Lusk's remark on this same case, Note on "A Case of Pancreatic Diabetes Mellitus" by Herman O. Mosenthal, The Archives Int. Med., 1912, $\mathrm{x}, 122$.

78. Dakin and Dudley: Jour. Biol. Chem., 1914, xvi, 515.

79. Minkowski: Arch. f. exper. Path. u. Pharmakol., 1893, xxxi, 85.

80. Brugsch: Therap. d. Gegenw., 1906, p. 337. Brugsch and Bamberg:

Zentralbl. f. d. ges. Physiol. u. Path. d. Stoffwechs., 1908, New Series iii, 1.

81. Allard: Arch. f. exper. Path. u. Pharmakol., 1908, lix, 388.

82. Minkowski: Arch. f. exper. Path. u. Pharmakol., 1908, lix, 395.

83. Gigon: Verhandl. d. Cong. f. inn. Med., 1909, p. 441. Mohr: Ztschr. f. exper. Path. u. Therap., 1907, iv, 910. Labbé: Rev. de Méd., 1912, pp. 257, 374.

84. Verzar and Fejer: Biochem. Ztschr., 1913, liii, 140.

85. Lattes: Biochem. Ztschr., 1909, xx, 215. Embden, Salomon and Schmidt: Beitr. z. chem. Physiol. u. Path., 1906, viii, 129. Dakin and Dudley: (Footnote 78).

86. Allen: Glycosuria and Diabetes, Boston, 1913, p. 615.

87. Those of Hurtley and Ondrejovich (Footnotes 113 and 114).

88. Hammarsten and Mandel: Text-book of Physiological Chemistry, 1912.

89. Marum: Beitr. z. chem. Phys. u. Path., 1907, x, 105.

90. Neubauer: Verhandl. d. Cong. f. inn. Med., 1910. Biochemische Arbeitsmethoden, 1910, v, 2, 1216.

91. Rosenfeld: Berl. klin. Wchnschr., 1908, p. 828.

92. Elias and Kolb: Biochem. Ztschr., 1913, lii, 331.

93. Ehrmann: Berl. klin. Wchnschr., 1913, 1, 13 .

94. Gigon: Ergebn. d. inn. Med. u. Kinderheilk., 1912, ix, 241.

95. Von Noorden: Die Zuckerkrankheit, 1912.

96. Labbé: Sem. méd., 1911, p. 506. Cammidge: Lancet, London, 1913, ii, 1319. Von Noorden: Med. Klin., 1913, ix, Part 1, p. 612. Hougounenq and Morel: Du coma diabétique, symposium, Sem. méd., 1911, No. 43, p. 505. 
97. Macleod, J. J. R.: Recent Work on the Physiologic Pathology of Glycosuria, Jour. Am. Med. Assn., 1914, 1xii, 1226.

98. Leschke: Arch. f. Anat. u. Physiol. (Rubner's), Phys. Abth., p. 411, (Footnote 14) "Bei dem intermittierenden Charakter der Glycosurien, die durch partielle Pankreas-Exstirpation entstehen, können über den Einfluss irgend eines Medikamentes auf die Glycosurie keine Schlüsse gezogen werden."

99. Compare Landsberg (Deutsch. Arch. f. klin. Med., 1914, cxv, 465) : "Heretofore only one kind of experimental diabetes has been known, which is not merely glycosuria, namely, pancreas diabetes" (bisher ist nur eine einzige Art des experimentellen Diabetes, der nicht nur Glycosurie ist, nämlich der Pankreas-Diabetes, bekannt).

100. Witzel: Arch. f. d. ges. Physiol., 1905, cvi, 173.

101. Hédon: Arch. internat. de physiol., 1911, x, 350.

102. It seems certain that Leschke (Footnote 14) was dealing with acute pancreatic deaths; his doses were large and the lethal effects marked.

103. Lattes: Arch. f. path. Anat., 1913, ccxi, 1.

104. After concluding the series of experiments described below, it has seemed that we must, before pursuing further the problems of opotherapy, go back a step to a more elementary problem, that of the exact nature of this clinical entity "acute pancreatic death." I am now approaching this by a different method from any hitherto applied to its solution; namely, by use of the Hédon technic of dislocating a lobe subcutaneously, retaining its vascular pedicle. This method was suggested to me by the occurrence in two dogs of the present series, in which the transplanted lobe underwent necrosis, of a sudden, toxic death, almost certainly identical with akute Pankreas Tod." The pancreatic enzymes were certainly not activated in this case by duodenal enzyme, unless by absorption and general circulation. I am now trying the effect of the local action, on this lobe, of bile, succus entericus, and of various infections, etc.; also the influence over the enzyme content of the blood.

105. Ringer and Fraenkel: Jour. Biol. Chem., 1914, xvi, 569.

106. Verzar and Fejer: Biochem. Ztschr., 1913, liii, 143.

107. Minkowski: (Footnote 79). Murlin and Kramer: (Footnote 34). I have often verified this.

108. Ferry: Jour. Path. and Bacteriol., 1914, xviii, 445.

109. Bang, Ivar: Ztschr. f. physiol. Chem., 1909, 1xiii, 443.

110. Benedict, S. R.: The Detection and Estimation of Glucose in Urine, Jour.

Am. Med. Assn., 1911, 1vii, 1193.

111. Folin: Am. Jour. Physiol., 1905, xiii, 45.

112. Malfatti: Ztschr. f. anal. Chem., 1908, v, 723.

113. Hurtley: Lancet, London, 1913, clxxxiv, 1160.

114. Ondrejovich: Deutsch. med. Wchnschr., 1912, xxxviii, 1413.

115. Lange: München. med. Wchnschr., 1906, liii, Part 2, p. 1764.

116. Embden and Schmitz: Ketones in Abderhalden: Handbuch der biochemischen Arbeitsmethoden, 1910, iii, Part 2, p. 908.

117. Gigon: Ergebn. d. inn. Med. u. Kinderheilk., 1912, ix, 293.

118. Embden and Schmitz: (Footnote 116, p. 914).

119. Pflüger: Glycogen in Abderhalden: Handbuch der biochemische Arbeitsmethoden, 1910, ii, 1075.

120. For literature see Pratt, J. H., and Spooner, L. H.: A Study of the Internal Function of the Pancreas in Carbohydrate Metabolism, The Archives InT. MEd., 1911, vii, 665.

121. Lüthje: Deutsch. Arch. f. klin. Med., 1904, lxxix, 498.

122. For instance, Table 1, p. 501.

123. It is notoriously difficult to obtain nitrogen equilibrium in carnivores unless enormous amounts of protein food are given, since the protein tolerance increases, advancing to higher and higher levels (Lusk, Graham: The Science of Nutrition, Philadelphia, Saunders, 1909, pp. 110, 111). 
124. In interpreting the tables given below, it must be remembered that there is no discrepancy between a "total acetone" figure of, say $0.0082 \mathrm{gm}$., and a negative qualitative acetone or diacetic test. For even the very sensitive Reynolds' test reacts only with $0.01 \mathrm{mg}$. in 1 c.c. water - which is about the equivalent (taking 400 c.c. as an average twenty-four-hour urine for a diabetic dog) to $0.004 \mathrm{gm}$. for twenty-four hours. All these qualitative tests are less sensitive when applied to urine, especially dogs' urine and particularly diabetic dogs' urine, than when applied to an aqueous solution of ketones, because of the high pigmentation of the former. The test used here (Legal-LeNobel-Lange) is not quite so sensitive as Reynolds' (Abderhalden: Handbuch der biochemischen Arbeitsmethoden, 1910, iii, Part 2, pp. 900-913). In general, varying of course with the concentration of the urine, a "total acetone" of below $0.09 \mathrm{gm}$. per diem will not give a qualitative color reaction to acetone. A diacetic (ferric chlorid) test will usually not be obtained with a "total acetone" much below $0.1 \mathrm{gm}$. per diem. These figures are for totally diabetic dogs, which usually run from 300 to 700 c.c. urine per diem. They correspond to about a 0.0225 per cent. (or $1: 4,500$ ) acetone solution, and to about a 0.025 per cent. (or $1: 4,000$ ) acetoacetic solution. However, my use of the quantitative measurements does away with the necessity of emphasizing qualitative results.

125. Labbé (Rev. de méd., 1912, pp. 257, 374), as also Azémar, cited by him, usually found acetone, but no diacetic acid in diabetic dogs.

126. Minkowski: Arch. f. exper. Path. u. Pharmakol., 1893, xxxi, 182.

127. For litreature see Gigon (Footnote 94).

128. Ehrmann: Berl. klin. Wchschr., 1913, 1, 12.

129. Macadam: Jour. Path. and Bacteriol., 1913, xviii, 284.

130. Galambos and Tausz: Ztschr. f. klin. Med., 1913, 1xxvii, 14. Loeffler: Ztschr. f. klin. Med., 1913, lxxviii, 483.

131. Magnus-Levy: Arch. f. exper. Path. u. Pharmakol., 1899, xlii; Ergebn. d. inn. Med. u. Kinderh., 1908, i, 352.

132. Ehrmann: Berl. klin. Wchnschr., 1913, 1, pp. 11, 65.

133. Embden and Michaud: Biochem. Ztschr., 1908, xii, 262.

134. Magnus-Levy: Ergebn. d. inn. Med. u. Kinderh., 1908, i, 352. Gigon: Ergebn. d. inn. Med. u. Kinderh., 1912, ix, pp. 285-295. Von Noorden: (Footnote 95 ).

135. Landergren: Nord. med. Ark., 1910, Part 2, No. 10, cited by Gigon: Ergebn. d. inn. Med. u. Kinderh., 1912, ix, 206. Embden and Engel: Beitr. z. chem. Phys. u. Path., 1907-8, xi, 323.

136. For literature see Hammarsten (Footnote 88). Magnus-Levy: Ergebn. d. inn. Med. u. Kinderh., 1908, i, 352. Gigon: Ergebn. d. inn. Med. u. Kinderh., 1912, ix, 206. Forssner: Skandin. Arch. f. Physiol., 1910, xxiii, 305. Landergren: Nord. med. Ark., 1910, Part 2, No. 10, cited by Gigon: Ergebn. d. inn. Med. u. Kinderh., 1912, ix, 206.

137. Biedl: Innere Sekretion, 1913, Ed. 2, Part 2, p. 344. Gigon: Ergebn. d. inn. Med. u. Kinderh., 1912, ix, 206, especially Zur Lehre von der Azidose, pp. 285-299. Magnus-Levy: Ergebn. d. inn. Med. u. Kinderh., 1908, i, 352.

138. There are various other interpretations of the exact way in which carbohydrate deficiency may result in ketogenesis (Gigon: Arch. f. d. ges. Physiol., 1911, cxl, 509), but the fact itself is firmly established.

139. Baer: Arch. f. exper. Path. u. Pharmakol., 1905-1906, liv.

140. For literature see Hammersten and Mandel: Text-book of Physiological Chemistry, 1912, pp. 508-515. Gross: Deutsch. Arch. f. klin. Med., 1912, cviii, 106.

141. Sandmeyer: (Footnote 73). Pratt: (Footnote 10). Abelmann: Ueber die Ausnutzung der Nährstoffe nach Pankreas-Extirpation, u. s. w., Inaug. Diss., Dorpat, 1890, cited by Allen: Glycosuria and Diabetes, Boston, 1913. Rosenberg: Arch. f. d. ges. Physiol., 1898, 1xx, 371. Lombroso: Arch. di fisiol., 1910, viii, 209. 
142. Pratt, Lamson and Marks: Tr. Assn. Am. Phys., 1909, xxiv, 266. Pratt and Spooner: (Footnote 9). Allen: Glycosuria and Diabetes, Boston, 1913, p. 996.

143. Thus Masuyama and Schild: Ztschr. f. phys. u. diät. Therap., 1900, iii, 451. Salomon: Berl. klin. Wchnschr., 1902, xxxix, 45. Meyer, E.: Ztschr. f. exper. Path. u. Therap., 1906, iii, 58. Ehrmann: Ztschr. f. klin. Med., 1909, 1xix, 319. With these and many other results, the negative findings of Gross have but little weight.

144. Minkowski : Berl. klin. Wchnschr., 1890, xxvii, 333; Arch. f. exper. Path. u. Pharmakol., 1908, lix, 395. Lombroso: Beitr. z. chem. Phys. u. Path., 1908, xi, 81 ; Ergebn. d. Physiol. (Ascher-Spiro), 1910, ix, 1, especially p. 11, Sammelreferat. Arch. di fisiol., 1910, viii, 209. Arch. di farm., 1910, ix, 446. Allard: (Footnote 81). Niemann: Ztschr. f. exper. Path. u. Therap., 1909, v, 466.

145. Abelmann: (Footnote 141). Hédon and Ville: Arch de physiol. norm. et path., 1897, xix, 606, 662. Gross: Deutsch. Arch. f. klin. Med., 1912, cviii, 106. 146. Levin: Arch. f. d. ges. Physiol., 1896, lxiii, 171. Hédon and Ville: (Footnote 145). Pratt and Spooner: (Footnote 9). Allen: Glycosuria and Diabetes, Boston, 1913, p. 996.

147. Minkowski: Berl. klin. Wchnschr., 1890, xxvii, 333. Lombroso: Beitr. z. chem. Phys. u. Path., 1908, xi, 81.

148. Lombroso: (Footnote 144). Brugsch: Ztschr. f. exper. Path. u. Therap., 1909, vi, 326.

149. Salomon: (Footnote 72). Ehrmann: Ztschr. f. klin. Med., 1909, 1xix, 319. Pratt: (Footnote 10). Gross: Footnote 140.

150. Reach: Biochem. Ztschr., 1911, xxxiii, 436.

151. Concerning the relation of acidosis to hepatic insufficiency. see: Allard: (Footnote 81). Friedmann and Maase: Med. Klin., 1910, xxxi, 445. Blum: München. med. Wchnschr., 1910, 1vii, 682. Neubauer: (Footnote 90).

152. A totally depancreatized dog has lost all ability to oxidize dextrose four days after the operation (Verzar and Fejer, Footnote 84).

153. Alien: Glycosuria and Diabetes, Boston, 1913.

154. Compare Mosenthal, E. Myer, Wegele. Allen himself admits this further on (Glycosuria and Diabetes, p. 815).

155. Pflüger: Arch. f. d. ges. Physiol., 1907, cxviii, 285: "Negative Beweise aber haben an sich keine entscheidende Kraft, wenn nicht der Beweis vorliegt, warum sie negativ sind."

156. "Ein negativer Erfolg kann durch verschiedene andere Gründe bedingt sein. So kann-um nur eine Möglichkeit zu erwähnen-die dem genzen Körper aus dem das Pankreas-Hormon volkommen verschwunden ist auf diese Weise zugeführte Menge immer noch zu klein sein, um eine zu Zuckerverbrennung genügende Konzentration zu erreichen." Pflüger, too, has admitted this (Arch. f. d. ges. Physiol., 1907, cxviii, 267).

157. Biedl: Innere Sekretion, 1913, Ed. 2, ii, 359: "Das gesamte Tatsachenmaterial über Pankreasdiabetes . . . spricht wohl entschieden dafür, dass hier bei ein inneres Sekret des Pankreas in Wegfall gekommen ist, welches de norma im Kohlenhydratstoffwechsel des Organismus eine ausschlaggebende Rolle spielt."

In addition to the references already cited the following will be found of interest.

Baer: Arch. f. exper. Path. u. Pharmakol., 1903-1904, li.

Burkhardt: Inaug. Diss., Greifswald, 1908, cited by Biedl.

Cohnheim and Klee: Ztschr. f. physiol. Chem., 1912, 1xxviii, 464.

Deucher: Cor.-B1. f. schweiz. Aerzte, 1898, xxviii, 321.

Ehrmann: Berl. klin. Wchnschr., 1913, 1, 11, 65.

Fleckseder: Arch. f. exper. Path. u. Pharmakol., 1908, lix, 407.

Forssner: Skandin. Arch. f. Physiol., 1909, xxii, 349.

Franke: Arch. f. klin. Chir., 1901, 1xiv, 364.

Geelmuyden : Ztschr. f. physiol. Chem., 1904, xli, 128, cited by Hammarsten. 
Gochel : Centralbl. f. Stoffwechs. u. Verdauungskr., 1900, i, 251.

Harley: Jour. Path. and Bacteriol., 1895, iii, 245.

Hess: Arch. f. d. ges. Physiol., 1907, cxviii, 536.

Jansen: Deutsch. med. Wchnschr., 1911, xxxvii, 1261 (ref.).

Keuthe: Berl. klin. Wchnschr., 1909, p. 47.

Labbé and Violle: Compt. rend. Acad. d. sc., 1912, cliv, 73.

Lépine: Sem. méd., 1895, xv, 169.

Lépine and Barrad: Compt, rend. Soc. de biol, 1891, cxiii, 1044.

Leschke: Die Pankreas Therapie des Diabetes, München. med. Wchnschr., 1911, 1viii, 1396.

Lombroso: Compt. rend. Soc. de biol., 1904, 1vii, 610; Jour. de physiol. et de path. gén., 1905, vii, 3 .

Lusk, Graham: Metabolism in Diabetes, Jour. Am. Med. Assn., 1910, Iv, 2105.

Minkowski: Berl. klin. Wchnschr., 1892, xxix, 90; Ergebn. a. allg. Path. u. path. Anat., 1896, i, 78.

Pflüger: Arch. f. d. ges. Physiol., 1908, cxxiv, 633.

Pratt, J.: Am. Soc. Adv. Clin. Investig., Sec. Ana. Mt., May 2, 1910, p. 6, cited by Mosenthal (Footnote 76).

Rubner: Ztschr. f. Biol., xv.

Sammet: Ztschr. f. physiol. Chem., 1913, 1xxxiii, No. 3, p. 212.

Sinn: Der Einfluss experimenteller Pankreasgang-Unterbindungen auf die Nahrungsresorption, Diss., Marburg, cited by Biedl.

Visentini: Arch. f. path. Anat., 1909, cxcv, 555; Jour. de phys. et de path. gén., 1910, 410 (review).

Weintrand: Arch. f. exper. Path. u. Pharmakol., 1894, xxxiv, 303.

Zunz and Mayer: Bull. Acad. méd. Bruxelles, 1905, cited by Allen. 